\title{
Tissue-Engineered Kidney Disease Models
}

\author{
Teresa M. DesRochers, Erica Palma, and David L. Kaplan ${ }^{\star}$ \\ Department of Biomedical Engineering, Tufts University, Medford, MA, USA
}

\begin{abstract}
Renal disease represents a major health problem that often results in end-stage renal failure necessitating dialysis and eventually transplantation. Historically these diseases have been studied with patient observation and screening, animal models, and two-dimensional cell culture. In this review, we focus on recent advances in tissue engineered kidney disease models that have the capacity to compensate for the limitations of traditional modalities. The cells and materials utilized to develop these models are discussed and tissue engineered models of polycystic kidney disease, drug-induced nephrotoxicity, and the glomerulus are examined in detail. The application of these models has the potential to direct future disease treatments and preclinical drug development.
\end{abstract}

\section{Keywords}

Renal; Polycystic Kidney Disease; 3D tissues; microfluidics; glomerulus; drug-induced nephrotoxicity; acute kidney injury; chronic kidney disease; renal fibrosis; renal cell carcinoma

\section{Introduction}

Tissue engineering can be broadly defined as the application of engineering principles to biological systems. A fundamental goal of tissue engineering is the regeneration of damaged or diseased organs which has been significantly advanced towards clinical use for organ systems such as skin, bone, bladder, and cartilage [1]. However, the regeneration of more challenging organs, such as the kidney, is not as advanced due to the complex composition and highly controlled functionality of the kidney. As such, the current strategy towards kidney tissue regeneration has focused on the development of simple building blocks that consist of a single cell type in a three dimensional (3D) environment in vitro. These simplified tissues are currently being applied to in vitro modeling of kidney diseases such as polycystic kidney disease (PKD), preclinical drug screening for nephrotoxicity, and understanding early kidney development. While these tissue engineered models will not replace the traditional experimental methodologies of 2D cell culture and animal models, they can provide relevant information that may compensate for the limitations of those

(C) 2013 Elsevier B.V. All rights reserved.

*Correspondence to: Phone: (617) 627-3251, david.kaplan@tufts.edu.

Publisher's Disclaimer: This is a PDF file of an unedited manuscript that has been accepted for publication. As a service to our customers we are providing this early version of the manuscript. The manuscript will undergo copyediting, typesetting, and review of the resulting proof before it is published in its final citable form. Please note that during the production process errors may be discovered which could affect the content, and all legal disclaimers that apply to the journal pertain. 
methodologies. In this review, we summarize the techniques utilized to form tissue engineered kidney disease models and examine the models being developed to study PKD and drug-induced nephrotoxicity (DIN) and other kidney diseases (Table 1). While this review will focus primarily on the tubule region of the nephron, where the bulk of previous work has been concentrated, we will conclude with a discussion of the steps being made towards developing disease models of the glomerulus.

\section{Why Tissue Engineering?}

Traditionally, human disease has been studied using human patients, animal models, and cells cultured two-dimensionally (2D) on plastic dishes in the laboratory. These modalities have all contributed significantly to the understanding of kidney diseases such as PKD and DIN. However, these modalities have limitations which need to be compensated for in order to continue the progression of our understanding of kidney diseases and the development of more effective, less toxic therapies.

Studying kidney disease in human patients through patient clinical information is the gold standard for studying human diseases as it allows for exact replication of patient physiology, genetics, and environment. However, this approach has significant limitations. Patient data often represents the later or end stages of disease, can vary drastically between patients due to a plethora of uncontrollable genetic and environmental factors resulting in the need for very large sample sizes, and is subject to the availability and willingness of patients to divulge information and/or allow tissue biopsies. Additionally, since genetic and biochemical experimentation on humans is rarely an option, the acquired data is often limited to patient observation and screening. Tissue engineered kidney models offer the possibility of examining the early stages of disease progression by using human cells in a traceable, controlled environment. The use of human cells in these models and the ability to manipulate the environment and genetics of these cells allows scientists to better understand the factors involved in the development of disease phenotypes.

Animal models are commonly used as a replacement method for the study of disease in humans. They provide a more controllable experimental system compared to human patients while still maintaining both the overall complexity of in vivo physiology and the organization of cells and other factors within organ systems. However, animals vary significantly from humans in terms of gene expression and physiology and the extremely controlled nature of animal experiments are not representative of human life [2]. These limitations often make it difficult to translate animal experimental results to human treatments [3]. Animal experiments are also expensive relative to 2D cell culture, highly regulated, and pose numerous ethical issues. Recently, the ethical principle of the 3Rs, replace, refine, and reduce, for animal experimentation has undergone a major push by the European Union and is also beginning to make significant progress in the United States [4]. The replacement of animal models with tissue engineered models has achieved progress in the European Union where cosmetic testing on animals has been replaced by the use of engineered skin models [5]. Meanwhile, funding agencies within the United States have recently made a push for the development of tissue engineered models of human organs for preclinical drug testing. Although these systems will not be used to completely replace 
animals in drug testing, they will contribute to a reduction in the number of animal studies performed and have the potential to generate significant experimental results.

Unlike animal models, 2D cell culture of human cells provides human data in easily exploitable, genetically controlled environments. This experimental methodology is simple, low in cost, and potentially high-throughput thus enabling the testing of numerous conditions and/or treatments in relatively short timeframes. However, cells in 2D lack the complex 3D tissue architecture and interactions found in vivo that are necessary for proper gene expression and function in the kidney [6], other organ systems [7,8], and different disease states [9-11]. Additionally, these cultures can only provide data on acute responses as both time and culture space limit their life span. Tissue engineered disease models have the potential to overcome the limitations of $2 \mathrm{D}$ cell culture by combining human cells in a genetically and environmentally controllable experimental system that is capable of mimicking the complex 3D architecture and interactions found in vivo. Furthermore, these tissues are capable of modeling both acute and chronic kidney disease as they are sustainable for weeks in static culture [6,12] and the use of bioreactor systems has the potential to extend culturing time further [13].

3D tissue engineered disease models are not, however, the answer to all the problems associated with current experimental modalities and their development includes many challenges. Currently, the specialized culturing conditions often require the purchase of disposables that are more expensive than traditional cell culture dishes along with bioreactors and fluid pumps that are costly and utilize specialized incubator space. Additionally, most traditional assays have been developed for 2D cell culture models. They are often incompatible with the 3D nature of engineered tissues. Further work needs to be performed to validate and standardize traditional assays for engineered tissues. As more academicians and companies develop these 3D tissue models, costs will be reduced and assays will be adapted for the unique aspects of 3D tissue models.

\section{Engineering Strategies}

The kidney is organized into numerous nephrons, each consisting of a renal corpuscle linked to a tubule region interlaced with the renal vasculature (Fig. 1) [14]. The renal corpuscle consists primarily of the glomerulus surrounded by Bowman's capsule and functions through the exact organization of glomerular endothelial cells, podocytes and mesangial cells around the specialized glomerular basement membrane to filter blood. The tubule region of the nephron is composed of a spatial alignment of epithelial cells that have location specific functions to remove water and other solutes from the glomerular filtrate. The vasculature and stromal tissues combine with the cells of the nephron to contribute to the overall function and complexity of the organ. Tissue engineering strategies combine three major components to mimic this complexity, a cell source, a scaffolding material, and the chemical solutes necessary to ensure cell growth, organization, and functional differentiation. In this section we will examine the source of the biological materials and different scaffolding strategies. 


\subsection{Sources of Biological Materials}

There are two major strategies for using cells in engineered kidney tissues. The first is to use individual cell types that can be coaxed into reforming the architecture and cell-cell contact found in vivo. The second is to use excised portions of organs thereby maintaining the overall architecture and correct spatial alignment of epithelial cell-cell contact found in vivo. This section will focus on the use of single cell suspensions while in vitro organ culture will be discussed in the section on DIN where it is most often utilized [15]. Non-adherent spheroid cell cultures used to study the mechanisms of renal cell carcinoma [16] and organ slice cultures [17-19] used to study DIN are not within the scope of this review and will not be discussed.

Cultured kidney cells are the simplest source of biological material for the development of tissue engineered models. There are numerous animal kidney cell lines that have been in use for decades, including cells from dog, pig, rabbit, rat, and opossum. More recently, human proximal tubule cell lines, HK-2 and RPTC/TERT, have also been developed, through different cell immortalization techniques. The gold standard continues to be primary cultures of human proximal tubule epithelial cells due to the genetic changes that result from the techniques used in cell immortalization and long-term cell passaging [20,21]. In this section we will discuss human primary versus immortalized tubule epithelial cells as well as the different animal cell lines used in tissue engineering strategies. Glomerular cells will be discussed within the context of glomerular tissue engineering.

3.1.1 Human Cells-The complex organization of the tubule region of the nephron and the heterogeneity of the epithelial cells involved makes it difficult to study specific epithelial cell types. Therefore, most 2D cell culture based kidney research has been performed with primary renal proximal tubule epithelial cells (PTC) which are relatively easy to isolate from the cortex of the kidney [22-24]. These cells are often isolated from the non-cancerous pole of kidneys removed due to renal cell carcinoma. However, they may also be removed from non-transplantable kidneys, normal kidney biopsies, or for the study of kidney diseases such as PKD, biopsies of diseased kidneys. These primary cells have been shown to lose the expression of key genes during passaging, so their use is limited to only 2-5 passages [25]. This restriction poses a significant problem in kidney research as new isolates must be obtained frequently leading to differences in the genetic background of the cells used between experiments.

To overcome these limitations, some groups have immortalized human renal PTCs. Ryan et al. immortalized renal PTCs with human papilloma virus (HPV16) E6/E7 genes in 1994 resulting in the cell line HK-2 [26]. They were able to show function representative of the proximal tubule and the expression of genes found in PTCs. However, work by other groups has shown improper gene expression of important functional markers. Baer et al. and Tang et al. both showed that HK-2 cells express aquaporin 3 which in vivo is only found in the collecting duct [27,28]. Additionally, toxicity studies have shown that HK-2 cells do not respond to nephrotoxins in a dose response manner similar to in vivo nephrotoxicity responses [29,30]. HK-2 cells have been shown to require extremely high doses to achieve a toxic response. For example, Wu et al. showed that cisplatin was not significantly cytotoxic 
to $\mathrm{HK}-2$ cells, requiring a dose of $1000 \mu \mathrm{M}$ and gentamicin has been shown to not be toxic to HK-2 cells even at a concentration of $1 \mathrm{mM}[30,31]$. This may be due to the loss of particular transport channels or other cellular machinery needed to process drugs in order to induce cytotoxicity. Despite these limitations, HK-2 cells have been used in a number of tissue engineering strategies [32-34]. When HK-2 cells are overlayed with a porcine collagen I matrix, they form tubular structures [33], and when induced to form tubules in microfluidic devices, they are more polarized, increase gene expression and kidney-like function, and are capable of forming calcium phosphate stones [32,34]. Future studies may show that HK-2 cells are not relevant for DIN, but they may be useful for understanding kidney development.

Other methods of cell immortalization have also proven successful for kidney epithelial cells. Wieser et al. immortalized renal PTCs using the human telomerase reverse transcriptase (hTERT) system resulting in the cell line RPTEC/TERT1 [35], which is capable of maintaining proximal tubule functions such as hormone mediated cAMP expression, $\mathrm{pH}$-dependent ammonia production, sodium-dependent phosphate uptake, and protein endocytosis. While RPTEC/TERT1 cells have yet to be utilized in tissue engineering strategies, DesRochers et al. utilized an hTERT immortalized proximal tubule cell line, $\mathrm{NKi}-2$, in a 3D tissue engineered model of kidney tubules [6]. These cells were able to maintain the expression of PTC markers and function between 2D and 3D culture indicating no change between $2 \mathrm{D}$ and $3 \mathrm{D}$ in this respect. However, in 3D they were capable of forming tubule structures, responded to nephrotoxins in a manner more similar to in vivo conditions than HK-2 [30], and, significantly, expressed specific transporters not expressed in 2D culture [6]. While immortalization with hTERT appears to provide a more in vivo-like renal PTC line, these cells lines have not been as extensively tested as HK-2 cells and more studies are needed. Additionally, the initial data by DesRochers et al. indicates that 3D culture of kidney cell lines may change their phenotype and help to make them more in vivolike in comparison to their growth in $2 \mathrm{D}$ cell culture.

Recent advances in immunomagnetic cell isolation and a better understanding of markers of specific kidney epithelial cell types have allowed the isolation of other kidney epithelial cell types, including the thick ascending limb and the early distal convoluted tubule. Using Tamm-Horsfall glycoprotein (THG) and immunomagnetic beads, Baer et al. were able to isolate cells with gene expression patterns similar to the thick ascending limb of the Loop of Henle and the early distal tubule which they named TALDC [27]. Prior to passaging, these cells maintained gene expression patterns similar to in vivo. However, passaging of the cells quickly resulted in the loss of expression of genes such as THG and the epithelial calcium co-transporter $(\mathrm{ECaC})$. Other groups have tried to exploit the differential expression of lectins across the epithelial cells of the kidney tubule to isolate different subgroups [36,37]. These cells have remained as primary cell isolates and no current immortalized epithelial cell lines exist beyond that of the proximal tubule. It is important to be able to isolate these different cell types for tissue engineering because of the controlled roles of the different epithelial cells composing the tubule portion of the kidney nephron (Fig. 1). These controlled roles also result in differential responses to nephrotoxic agents making the isolation of these different cell types critical for DIN studies. 
While proximal tubule cells have comprised most of the current kidney tissue engineering studies, eventual engineering of a complete kidney nephron will require the isolation and/or generation of all cells of the kidney nephron. Future studies must be performed to develop robust methods of isolating the different cell types of the tubule region and maintaining them in culture conditions capable of retaining key protein expression. It may be necessary to generate these different cell types as immortalized cell lines in order to avoid the potential complications added by the genetic diversity of patients which is a concern with the constant isolation of primary cells. iPSCs also represent an option for the generation of the different cell types in the kidney. Work in this direction is relatively new and should continue to progress $[38,39]$.

3.1.2 Animal Cells-While there are a number of animal kidney cell lines available, Madin-Darby canine kidney cells (MDCK) isolated from the kidney tissue of a dog are one of the most utilized in tissue engineered kidney models because of the tendency of the cells to form polarized cysts with the apical side facing the central lumen in collagen I hydrogels $[40,41]$. This is critical as it correctly mimics the polarity of cells in vivo and indicates correct contact orientation with the extracellular matrix (ECM). These cells branch and migrate into collagen I hydrogel in the presence of hepatocyte growth factor (HGF) [42], are used to study the mechanisms involved in polycystic kidney disease [43,44], and have been utilized to study ifosfamide induced nephrotoxicity in microfluidic devices $[45,46]$. However, these cells are a heterogeneous population of kidney epithelial cells, they are not of human origin, and they do not have the same phenotype in 3D tissue culture as human renal PTC [47]. As human kidney cell lines increase in number and specificity, researchers may move away from the study of MDCK.

\subsection{Scaffolding}

Engineering a tissue requires 3D growth that facilitates the formation of complex architecture in vitro and/or the incorporation of other factors such as shear forces due to fluid flow and proper cell compartmentalization. The use of hydrogels and microfluidic chips will be examined in this section. Other scaffolding systems such as decellularized kidneys have also been utilized to grow kidney cells in vitro and these will be discussed briefly.

3.2.1 Hydrogels-In order to facilitate 3D growth, the scaffolding material used must be capable of remodeling and must provide a signaling mechanism to promote proper cell function, gene expression, and organization. Biopolymer based hydrogels have been the overwhelming choice for kidney tissue engineering due to their ability to be remodeled while still presenting cell signaling cues similar to that found in vivo. These hydrogels take a number of forms including different animal derived collagens [33,48], Matrigel, a basement membrane protein mixture extracted from Engelbreth-Holm-Swarm (EHS) mouse sarcoma [49], a mixture of collagen type I and Matrigel [6], or hyaluronic acid [50,51]. Cells or tubule pieces are most often embedded within these gel systems and form randomly spaced and aligned structures on their own. The benefit of this random seeding is that it allows for the observation of how the cells will behave in 3D and their response to the surrounding cues. However, hydrogels may also be used to examine other factors of kidney tubule 
morphogenesis and disease progression. Manivannan et al. patterned collagen type I into channels using polydimethylsiloxane (PDMS) molds. These channels were then seeded with MDCK cells and covered with a collagen type I lid [42]. This system enabled controlled tubule formation and allowed the tracking of cell migration in 3D. Moll et al. adapted a hydrogel model often used for the development of organotypic skin [52] where fibroblasts were seeded within a collagen type I hydrogel and human kidney PTC were grown on top of the hydrogel [48]. This system allowed the examination of the change in fibroblasts upon DIN in the presence of epithelial cells towards an activated myofibroblast phenotype as assessed by RTPCR. Examining the same cells in all these systems has the potential to provide extensive insight into cell growth in 3D and the factors involved in their organization and interaction with other cell types.

There are numerous factors that play a role in 3D cell morphology within hydrogels, including mechanical signals and protein interactions. Stiffness and tension are known to be a factor in cell response and can be modulated by changing the protein concentration of the hydrogel [53,54]. A second major factor is the protein-protein interactions that may occur between proteins on the cell surface and the proteins found in the hydrogel $[55,56]$. Collagen and Matrigel based hydrogel systems use biological materials extracted from animals, and their complexity makes it difficult to directly determine the specific protein-protein interactions involved in cell 3D morphology. Chung et al. developed a hydrogel based system that has allowed some of the protein-protein interactions to be clarified [41]. By tethering bioligands such as the integrin ligands RGD and laminin to protease-sensitive cross-linkers attached to a PEG-based hydrogel, the authors were able to find evidence of a role for integrin binding in renal cyst formation in 3D. These customizable hydrogels have the potential to reveal the cell-ECM interactions necessary for tubule morphogenesis, glomerular disorders, and cancer progression.

The major limitation of collagen based hydrogels is fast degradation due to cellular remodeling and relatively low mechanical integrity, which reduces their ability to withstand shear forces imposed by fluid flow and limits their utility for sustained cultivation [57]. To overcome these issues while maintaining the in vivo like signaling mimicked by these systems and the 3D cellular organization, Subramanian et al. $[13,58]$ combined a collagen based hydrogel with a porous silk scaffold. The cells did not interact with the silk scaffold but formed structures within the hydrogel that filled the pores. The relative rigidity and very slow degradation of the silk scaffold allowed the cultures to survive for at least 6 weeks in a perfusion bioreactor with retention of tissue structure and function. These porous silk-based scaffolds may facilitate the formation of tissue engineered kidney that can be used to study chronic kidney disease over extended periods of time.

Most tissue engineered models of the kidney last less than a week in culture. This eliminates the ability to fully mimic the development of chronic kidney diseases such as PKD in which cysts develop over the course of decades in patients or DIN caused by long-term repeat dosing of drugs. The goal of kidney tissue engineering for disease modeling should be to develop a tissue engineered kidney that can survive in culture and be studied at least as long as an animal study would run. However, in vitro culture length has remained a problem for all tissue engineered organ systems. The combination of cells capable of remaining 
functional, alive, and nonproliferative for long periods of time, scaffolding materials capable of directing and/or facilitating this long lifespan, and bioreactors capable of facilitating proper nutrient delivery is necessary for achieving this goal. Both Subramanian et al. and DesRochers et al. described culturing systems that lasted 6 weeks or more without cellular overgrowth even in systems comprised of immortalized cells $[6,13]$. This may indicate an inherent property of the 3D system capable of maintaining kidney epithelial cells in a more senescent state than the 2D system. The combination of these 3D systems with the fluid flow technology of microfluidics may lead to long-term sustainable culture systems capable of mimicking chronic diseases.

3.2.2 Decellularized Kidneys-While decellularized kidneys are a relatively new advance, techniques have been developed to decellularize rat [59-61], porcine [61-63], rhesus monkey [64-66], and human [61] kidneys with the benefit being that decellularized organs maintain the complex architecture and native biological signatures of in vivo organs. Numerous groups have shown the ability to seed these decellularized kidneys with either mouse $[59,60]$ or human [66] embryonic stem (ES) cells. The ES cells were capable of migrating and proliferating in the decellularized organs, could remodel the ECM [60], and were shown to express some markers of different lineages, including kidney-specific cadherin [59], Pax-2 [59], and the endothelial specific lectin, BsLB4 [60]. However, there is some question as to the specificity of the differentiation of ES cells in decellularized organs as little difference was seen in the expression of specific genes between human ES cells grown on decellularized kidney or lung [66]. The ability to maintain native architecture, ECM function, and mechanical integrity make decellularized organs specifically appealing for tissue regeneration. Song et al. recently implanted into a rat, a decellularized rat kidney that had been reseeded with human unbilical vein endothelial cells (HUVECs) and a heterogeneous mix of rat neonatal kidney cells [61]. Blood perfused throughout the system in vivo with no evidence of parenchymal bleeding or clot formation. The implanted kidneys produced less urine with lower creatinine and urea that the native kidney, but they had improved glucose and albumin secretion into the urine compared to implanted decellularized kidneys. Future studies should examine the ability to reseed and implant larger kidneys such as porcine that may have a more direct application to human patients and may assist in reducing the number of patients waiting long periods of time for transplant organs. These decellularized organ systems also have the potential to serve as modeling systems for diseases such as PKD, however they inherently lack the capacity for high-throughput studies.

3.2.3 Microfluidic Devices-Organ on a chip technology utilizing microfluidics in which cells are seeded into defined channels has been recently developed to examine the effects of fluid induced shear forces on cells [67]. This is particularly significant for the kidney nephron as changes in fluid flow have been linked to kidney cell function and diseases such as PKD [68-71]. There are two major strategies for the formation of these devices involving seeding kidney epithelial cells on replica molded PDMS [45,46,72] or onto porous membranes underlying patterned, microfluidic channels [34,73-75] although $\mathrm{Mu}$ et al. have recently developed a technique to form microfluidic channels within a hydrogel [76]. Often these devices are coated with an ECM protein to enhance cell attachment, proliferation, 
and/or phenotype. Baudoin et al., and Choucha-Snouber et al. used fibronectin [45,46,72], Jang et al. used collagen type IV [34], and Gao et al. used Matrigel after comparing it to collagen type I, laminin, and gelatin [74]. The cells utilized have included HK-2 [32,75], primary human renal proximal tubule epithelial cells [34,74,75], MDCK [45,46,72], and rat inner medullary collecting duct cells [73]. In all cases, the epithelial cells formed confluent monolayers within the microfluidic channels as they do in static culture. The addition of shear stress from fluid flow induced a columnar shape to the cells and increase their height [34,73]. Cells cultured under shear stress also increased the expression of ion channels, transport proteins, and the number of cells expressing primary cilia compared to static culture $[32,34,46]$. Jang et al. also showed an increase in functional responses such as albumin uptake and glucose transport compared to static culture [34]. The increase in gene expression and function caused by fluid flow induced shear stress indicates that they have the potential to function as relevant kidney disease models. Wei et al. has explored this issue by using their model to look at the formation of kidney stones [32]. Through the addition of $\mathrm{CaCl}_{2}$ and $\mathrm{Na}_{3} \mathrm{PO}_{4}$ to the system lined with HK-2 cells, they were able to monitor the formation of calcium phosphate deposits with Confocal Raman microscopy. While the direct addition of these compounds removes some of the natural in vivo influence, this system may serve in the future as method for understanding the kinetics and mechanism of kidney stone formation. In addition, both Jang et al. and Choucha-Snouber et al. have applied their systems to the study of DIN $[34,45,46]$. The results of these studies will be discussed further in the section on DIN.

For the most part, these devices remain similar to 2D cell culture in the fact that the cells are still seeded in a monolayer without surrounding support cells or encasement in ECM. The technique developed by $\mathrm{Mu}$ et al. however represents a hybrid of 3D hydrogel models and microfluidic models by incorporating the microfluidics within a hydrogel thereby ensuring that the cells are surrounded by and in contact with ECM [76]. The authors were able to show the ability to seed different cell types in different compartments and that passive diffusion from one compartment to another was possible. While this has the possibility to be a 3D-microfluidic hybrid model, much work is necessary. Further research should include functional and structural examination of different kidney epithelial cells within the system in conjunction with endothelial cells in the adjoining compartments. It could be that the crosstalk will facilitate better, more in vivo like kidney cell function and induce more relevant structural aspects such as tight junction formation and transporter expression. This represents a step forward in the increased complexity of microfluidic systems.

\subsection{Bioreactors}

Fluid filtration is the key function of the kidney. This is accomplished in vivo through the regulation of fluid flow throughout the glomerulus and the tubule region of the kidney nephron. The shear stress induced by this fluid flow is critical for proper cell function and is detected in vivo by cilia on the surface of epithelial cells $[77,78]$. Replication of this fluid flow in vitro is critical for the study of diseases such as Autosomal Dominant Polycystic Kidney Disease (ADPKD) that are characterized by the formation of fluid filled cysts and are due to the loss of genes that encode proteins associated with cilia function [79]. However, most in vitro systems use static culture conditions in which media is changed 
every few days. Perfusion based fluid flow is better suited for the in vitro replication of in vivo kidney function and is accomplished in vitro through the use of bioreactor systems. Microfluidic systems are good examples of these systems, as they have revealed differences in cell morphology [34,73], gene expression [32,34,46] and cell function [34] when fluid flow is utilized. Additional benefits of perfusion bioreactor systems are the ability to sustain cultures for longer periods of time [13] and subject cells to drugs and other substances under conditions more representative of in vivo conditions [34]. A major factor of perfusion based fluid flow that must be considered is the force generated by that flow and how it relates to different kidney disease states in vivo. Proper regulation of fluid flow may lead to bioengineered models that better replicate different disease states.

\subsection{Summary}

We have described work being performed in three major areas, cells, scaffolds, and bioreactors, that will need to be combined in the future for the generation of more accurate tissue engineered kidney disease models. The cellular complexity of the kidney makes the generation of functionally relevant and genetically accurate cell lines critical for further work. These cell lines must be capable of performing specific functions thus reflecting the roles of their in vivo counterparts, and long-term culture will be an eventual requirement as models move towards chronic testing. Additionally, in order to standardize systems, it will most likely become necessary to move away from the genetic diversity inherent to primary cells that come from different donors. These criteria may be achieved through the development of better immortalization systems or further work in the differentiation of iPS cells. Progress towards more accurate models capable of long-term culture will also require the development of scaffolding systems that reflect the in vivo ECM, including protein composition and organization and material stiffness. Hybrid systems, such as the silk/ hydrogel system described by Subramanian et al. $[13,58]$ and the hydrogel/microfludic system described by $\mathrm{Mu}$ et al. [76] represent the direction necessary for accurate, chronic disease modeling. Finally, the development of bioreactors capable of mimicking the fluid flow of the kidney must be combined with scaffolding/cellular systems to induce the phenotypes mediated by fluid flow as well as facilitate long-term culture and chronic disease modeling. The pieces of the puzzle are in development and continuing work will slowly bring the pieces together with the eventual goal being the development of accurate, sustainable kidney disease models.

\section{Polycystic Kidney Disease}

The term polycystic kidney disease (PKD) describes a group of inheritable disorders which result in the formation of fluid filled renal cysts that can lead to end stage renal disease [80]. ADPKD, the most common form of PKD, affects over 600,000 people in the United States [80,81]. Over 4 percent of ADPKD patients require renal replacement therapy and while there are ongoing clinical trials there are currently no therapeutic treatments for ADPKD [80,82]. Mutations in the genes $P K D 1$ and $P K D 2$ are the source of $85 \%$ and $15 \%$ of clinical cases of ADPKD, respectively [83]. The primary methods for investigating the pathogenesis ADPKD include patient data, animal models, cell culture studies, and tissue engineered models. In vitro tissue models have been critical for advancing the understanding of the 
disease pathogenesis with respect to cyst fluid secretion, cell proliferation pathways, and extracellular matrix interactions. This section will touch on the most prevalent PKD models and the utility of these approaches.

\subsection{Animal Cell Models}

Animal models of PKD benefit from utilizing readily available, well characterized cell sources that either naturally form polarized cysts, as is the case for MDCK cells, or can be genetically manipulated to present the desired phenotypic characteristics $[58,84]$. The transition from the underlying genetic mutation to a cystic phenotype is the result of a complex molecular signaling cascade that is not yet fully understood [83]. Due to the ready availability of animal cells, tissue engineered animal cell models have been the primary models utilized to elucidate the effects of specific signaling pathways on cyst development.

4.1.1 MDCK Models-Typical tissue models of PKD involve culturing MDCK cells in collagen type I hydrogels [44,84-86]. MDCK cells are a heterogeneous cell source with varying morphologies and functional phenotypes between clones [87]. In order to reproducibly work with MDCK cells as a model system, Granthem et al. established a homogenous cell population by collagenase digestion of MDCK containing hydrogels and subculturing cells derived from a single cyst [84]. MDCK cultures assume a cystic phenotype in collagen hydrogels and can be stimulated to undergo tubulogenesis through the addition of HGF [44]. Localization of polycystin-1 (PC1), the gene product of $P K D 1$, has been shown to vary depending on the morphology of these cultures; PC1 was shown to be diffusely expressed in the cystic phenotype but localized to the membrane during lumen formation [44]. A strength of the MDCK model is that this localization pattern observed in vitro mimics the presentation of $\mathrm{PC} 1$ in vivo [43]. However, it is important to note that this approach does not capture the full complexity of $\mathrm{PC} 1$ expression associated with the disease phenotype. ADPKD develops due to a somatic cell loss of heterozygosity in PKD1 or PKD2 that subsequently reduces the level of functional polycystin below the threshold required for normal cellular behavior [88]. To better mimic the disease phenotype genetic alterations have been made to the initial MDCK PKD to include physiologically relevant pathways. Liu et al. stably over-expressed membrane-bound type 1 metalloproteinase (MT1-MMP) in MDCK cells which has been found at higher serum levels in PKD patients [89,90]. This addition of matrix remodeling ability to the culture resulted in greater cyst growth which was reversible in the presence of an MMP inhibitor.

Early implementation of these models demonstrated the usefulness of this approach for studying the role of transepithelial fluid secretion in cyst expansion. Systematic testing of transporter inhibitors such as ouabain, which targets the sodium potassium pump, demonstrated the basolateral to apical transport of chloride and water [84]. Appropriate to the disease phenotype, chloride mediated cyst expansion has been shown to be dependent on the cystic fibrosis transmembrane conductance regulator (CFTR) in MDCK models after CFTR inhibition [86]. Based on the feasibility and the functional relevancy of the MDCK model, recent studies have characterized the effect of novel therapeutic targets on cyst development [91-93]. Takiar et al. slowed cystogenesis in three models of PKD using the adenosine monophosphate activated protein kinase (AMPK) activator metformin [93]. 
AMPK targeted both cell proliferation and secretion through inhibition of mammalian target of rapamycin (mTOR) signaling and CFTR activity. The consistency of the result between the MDCK model, metanephritic nephron culture, and inducible PKDl inactivation in in vivo mouse models supports the efficacy of the MDCK model. At the same time, the need to simultaneously test therapeutic targets in tissue culture explants and in vivo demonstrates the need for a more complex in vitro model. MDCK based models automatically undergo cytogenesis without genetic perturbation, currently utilize only a single cell type and do not incorporate the fluid induced shear stresses that kidney epithelial cells experience in vivo.

4.1.2 Mouse Cell Models-Recently developed PKD models using mouse cells are less established but incorporate a greater level of complexity not found in prior MDCK cell models. Montesano et al. established a tubule to cyst conversion model using immortalized mouse collecting duct cells (mCCD) in a collagen-Matrigel drop culture [94]. After selecting a subclone, identified as N21, of the mCCD cells which formed organized tubular structures, well-defined lumen and polarized epithelium, cyst formation was induced through the addition of a cyclic adenosine monophosphate (cAMP) agonist. cAMP agonists such as forskolin are known to increase cyst enlargement and formation in 3D cystic cultures [85]. Although cAMP levels are elevated in renal cells of PKD animals the physiological source is not yet fully understood [95].

The small matrix volume of the model developed by Montesano et al. makes the system amenable to high-throughput measurements but also limits the potential culture length [94]. Cyst development in vivo is gradual thus extended culture length is a relevant characteristic to consider with respect to understanding cytogenesis and long term testing of therapeutics. By infusing a mixture of collagen type I and Matrigel into a porous silk protein scaffold and culturing in a bioreactor, Subramanian et al. were able to maintain viable co-cultures of PKD1 $1^{\text {null/null }}$ mouse embryonic kidney cells and fibroblasts for 8 weeks [13]. This approach yielded both tubule and cystic structures and functional organic anion transporter expression. To further investigate this approach, Subramanian et al. adapted the model by utilizing mouse Inner Medullary Collecting Duct cells (mIMCD) with stable knockdown of PC1 within their collagen type I/Matrigel/porous silk scaffold construct [58]. This model demonstrated the involvement of abnormal ECM deposition, integrin interactions, and cell cycle control in cyst formation similar to the in vivo human disease phenotype. Further investigation of transporter functionality and cell signaling activity in this model is needed to understand its utility for investigating pathways implicated in PKD. To date, there have been no drug targets tested in this model.

\subsection{Human Cell Models}

There have been relatively few changes to the human cell based models of PKD over the last two decades [96]. The most prevalent bioengineered approach for modeling PKD using a human cell source is the use of primary epithelial cells isolated from cysts of ADPKD patients cultured in collagen type I gels [97-101]. Cyst formation by primary ADPKD cells is typically induced using forskolin and epidermal growth factor [97]. Although ADPKD epithelial cells can assume a cystic phenotype when cultured in gels they are unable to undergo tubulogenesis as seen with normal human kidney cells $[6,96]$. The lack of a tubule 
phenotype limits this model to analyzing pathways associated with cyst expansion. Kher et al. has established a tubule to cyst model, where HK-2 cells form tubule structures in collagen gels, before microinjecting adenovirus expressing cadherin- 8 into the tubule space to induce cyst formation [33]. While cadherin-8 expression is found to be present in cystic epithelia this approach did not result in phenotypical cysts consisting of a single epithelial cell layer.

Human ADPKD cystic models demonstrate cAMP driven chloride secretion and repressed cyst growth in the presence of CFTR inhibitors such as glibenclamide [97,98]. This functionality significantly adds to the utility of the model. Jansson et al. were able to stimulate cyst growth in the presence of endogenous concentrations of ouabain using this approach [101]. Recently the functional phenotype of the model has been used to test potential treatments for PKD such as tolvaptan and sorafenib [99,100]. The small molecule raf inhibitor sorafenib was shown to reduce extracellular signal regulated kinase activity and subsequently cAMP dependent cell proliferation which ultimately blocked cyst formation [99]. Other studies using an alternative small molecular raf inhibitor produced the same in vitro results but additionally observed increased renal fibrosis in rat models [102]. This case highlights the limitations of using in vitro models which do not capture the complexity of in vivo kidney tissue. Swenson-Fields et al. recently established a co-culture of ADPKD cystic epithelial cells with a mouse RAW macrophage cell line [103]. While this approach did yield a greater total number of microcysts it did not investigate whether the macrophages were stimulated to polarize to an M2-like phenotype as observed in 2D and in vivo. Macrophages are typically associated with kidney tissue repair after injury and recent studies suggest macrophages stimulate cystic epithelial cell proliferation in PKD [104]. While further studies are necessary to understand the complete role of macrophages in PKD progression the addition of macrophages to in vitro tissue models further adds to the signaling complexity of the model.

\subsection{Additional Considerations}

The current available tissue engineered models are largely used in studies in conjunction with 2D cell culture, metanephritic nephron culture, animal models, or patient data. To increase the relevancy of in vitro models future models should seek to incorporate more pathophysiological components such as fluid flow and genetic mutation. The inclusion of fluid flow is particularly pertinent to PKD modeling considering the localization of the polycystin proteins to the primary cilia which is known to act as a mechanotransducer in kidney epithelial cells $[105,106]$. A model which incorporates the appropriate genetic foundation is also desirable considering that the loss of haplosufficiency is not completely understood [107]. As of now there are currently no approaches which achieve tubule to cyst conversion through genetically mimetic mechanisms thus limiting the ability to use in vitro tissue models to study disease pathogenesis.

\section{Drug-induced Nephrotoxicity}

Clinical drug trials are incredibly expensive, costing between 0.8 to 1.7 billion dollars, time consuming, lasting on average 9 years, and have a low success rate with only about $8 \%$ of drugs reaching the market [108]. Relevant and accurate preclinical screening of drugs is 
imperative to reduce the number of unsuccessful drug candidates that enter clinical trials. The FDA's Critical Path Initiative calls for the development of better tools to improve the success of drug candidates that proceed from pre-clinical testing to clinical trials [108]. Included in this process is the development of tissue engineered models better capable of predicting drug-induced toxicity in human subjects. The kidney is especially susceptible to drug-induced toxicity as it receives about $25 \%$ of cardiac output which upon ultrafiltration by the glomerulus becomes highly concentrated as it flows through the nephron on the path towards excretion [109]. About 7\% of drug candidates fail due to nephrotoxicity in preclinical testing with traditional methodologies [110], while it is estimated that $30-50 \%$ of all cases of severe acute renal failure in patients are due to drug-induced nephrotoxicity $[110,111]$, thus indicating a disconnect between the data generated by traditional methods and human in vivo response [112,113].

The ultimate goal of tissue engineering for the prediction of drug toxicity is the development of model systems that have the ability to accurately indicate human patient responses. The current approach consists of combining the data obtained from 2D cell cultures and animal models. However, this method is not very predictive as indicated by the low success rates of drugs that make it to clinical trials [2,108,113]. 2D cell cultures are only capable of mimicking an acute response due to their limited growth in vitro and animal models often represent only ideal conditions which are not indicative of relevant human physiological conditions [2]. Tissue engineered models containing human cells have the potential to better mimic the human response due to their ability to reveal both acute and chronic responses. In this section we will examine the limited number of tissue engineered models being developed to specifically study DIN and the challenges involved in translating those models to in vivo data.

\subsection{Animal Cell Models}

Tissue engineered animal cell models to study DIN may seem redundant as in vivo models already exist. However, if these methods can be developed to be high-throughput and reliant upon immortalized cell lines rather than the continuous isolation of cells or tubules from animals, they have the potential to cut down on costs and ethical dilemmas through the reduction of the number of animals required to get a drug past preclinical testing of drug absorption, distribution, metabolism, and excretion (ADME). The traditional methods have been 2D culture of animal cells, suspension cultures of animal tubule fragments [114-116], and animal kidney organ slices [19]. Astashkina et al. has recently made progress towards a tissue engineered system by combining a 3D hydrogel based method with excised mouse kidney tubules that are traditionally used to study DIN when cultured ex vivo [50,51]. They were able to grow the tubules in $3 \mathrm{D}$ for up to 6 weeks and maintain a more in vivo-like nephrotoxic response that immortalized cell lines. That same group went a step further and examined how their organoid cultures compared to the secretion of predictive kidney injury markers such as kidney injury marker 1 (Kim-1), neutrophil gelatinase-associated lipocalin (NGAL), clusterin, and N-acetyl- $\beta$-(D)-glucosaminidase (NAG) [50,117]. The model may be improved through the addition of fluid flow through the tubules. One of the main problems with whole tubule in vitro cultures is that the basolateral side tends to be in contact 
with the tested compound as the ends of the tubules can close up over time; however this is not the side that would be in contact with the drug in vivo [15].

As mentioned previously, one way to mimic directed fluid flow through a tubule in vitro is through the use of microfluidics. Choucha-Snouber et al. has developed such a model using MDCK cells to examine ifosfamide DIN $[45,46]$. They were able to show that the genetic response to ifosfamide differed between MDCK cells in static 2D cell culture and those exposed to fluid flow in the microfluidic device [46]. Importantly, ifosfamide is only nephrotoxic after it is metabolized in the liver. To study the interaction of the liver and the kidney, Chocha-Snouder et al. linked a liver microfluidic chip to a kidney microfluidic chip. The nephrotoxicity of the ifosfamide metabolite chloroacetaldehyde was previously studied by applying it directly to kidney cells. This co-culture microfluidic model allowed for the application of ifosfamide to the liver cells, HepRG, which metabolized it as it flowed through to the MDCK cells. They were able to show that the MDCK cells experienced the same level of toxicity when ifosfamide was applied to the liver/kidney co-culture model as when chloroacetaldehyde was applied to the kidney monoculture microfluidic model, while direct application of ifosfamide to the kidney monoculture did not result in toxic cell loss. Importantly, they also showed that this was specific to the cell type they chose to use for the liver portion of the co-culture as $\mathrm{HepG} 2 / \mathrm{C} 3 \mathrm{a}$ cells did not produce the same results. This is most likely due to differences in the expression of metabolizing enzymes between the two liver cell lines and highlights the importance of cell line selection.

\subsection{Human Cell Models}

Tissue engineered human models have been used for toxicity testing for both human liver [118-121] and skin [122-124], but very few tissue engineered kidney models have been applied to the study of human DIN. DesRochers et al. used a suspension of immortalized human PTCs in a hydrogel consisting of a mixture of collagen type I and Matrigel to study the toxic effects of cisplatin, doxorubicin, and gentamicin over a two week time course with multiple dosing [6]. Lactate dehydrogenase (LDH) secretion was used as the main readout and revealed a difference in the overall toxicity and timing of toxic events between $2 \mathrm{D}$ and 3D culture conditions of the same cell line. Additionally, they examined the secretion of two predictive kidney injury markers, Kim-1 and NGAL. The authors were able to show the usefulness of the markers for the tracking of DIN in 3D versus 2D cultures. Significantly, this work revealed that 3D tissues tend to be more sensitive to lower concentrations of drugs than 2D cultures which has been a problem noticed by other groups examining gentamicin toxicity in 2D cell cultures and patients [30,125]. This tissue engineered model requires further validation to show that this response is due to the ability of the engineered tissues to better mimic the process of drug uptake, metabolism, and toxicity found in vivo.

The difficulty in translating in vitro 3D tissue work to in vivo data remains a major roadblock. The addition of bioreactor systems that will allow for continuous fluid flow that better mimics the exposure of the nephron to drugs than a static culture system may help overcome this problem. Microfluidic systems are currently being developed that have the potential to address this need [34]. Jang et al. looked at a $100 \mu \mathrm{M}$ concentration of cisplatin applied for 24 hours in a microfluidic device containing primary human PTCs compared to 
the same cells in static culture. The results revealed that cells under fluid flow are just as responsive to cisplatin as cells in static culture, but are healthier to begin with as indicated by lower levels of LDH release at baseline compared to static culture cells, thus resulting in a more representative toxicity response than static culture. Additionally, they showed that the cells under fluid flow were almost completely protected from a toxic response to cisplatin when an OCT-2 inhibitor was administered at the same time as drug. The toxic response of cells in static culture was only partially inhibited under the same conditions. To further show the relevance of the model to in vivo data, Jang et al. showed that the cells under fluid flow were better at recovering from cisplatin toxicity than the cells in static culture. In conjunction with the microfluidic system, the 3D kidney model by DesRochers et al., revealed that the 3D static cultures were similar to 2D static cultures in their overall toxic response to cisplatin while the rate of peak toxicity was different [6]. In contrast to the microfluidic model by Jang et al., the 3D tissue model by DesRochers et al. was capable of tracking DIN over the course of 2 weeks while the microfluidic model was only dosed with drug for 24 hours. This may be due to the differences in culture conditions that result in cell overgrowth similar to 2D cultures in the microfluidic model which is not an issue with the 3D model. The combination of a 3D microenvironment and fluid flow induced shear stress may be necessary to truly mimic in vivo DIN and may result in a more physiologically relevant in vitro model of chronic DIN.

\subsection{Additional Considerations}

A physiologically relevant human tissue engineered model of DIN will accurately predict human toxicity levels, the mechanism of drug metabolism and toxicity, acute versus chronic responses, and the response of patients already suffering from acute kidney injury or chronic kidney disease. Precise recapitulation of the mechanisms of drug metabolism and toxicity may be accomplished through future work towards the development of more relevant cell lines and microenvironments. The ability to reveal chronic responses has the potential to emulate the toxicity of repeat drug doses which may be more relevant to clinical practice. Finally, DIN is often far worse in patients who are already suffering from acute kidney injury or chronic kidney disease and these patients are rarely modeled in 2D or animal models and are often also left out of clinical trials [126]. Tissue engineered models using human cells and mimicking these conditions hold the potential to help these patients and better guide dosing in the administration of drugs to patients at high risk of developing DIN. Accurately predicting human toxicity levels from in vitro cultures will remain a major roadblock until in vitro tissue engineered models of DIN are fully developed and understood.

\section{Other Kidney Disease Models}

Other models of kidney disease and function exist aside from ADPKD and DIN, but they have not been as extensively developed. These include models designed to study renal fibrosis [48], renal cell carcinoma [12,127-129], and nephronophthisis [130]. Renal fibrosis leads to the loss of functional nephrons within the kidney resulting in an increase in workload for the remaining nephrons which then results in an increase in tubular cell injury and inflammation triggering more fibrosis correlating with the progressive loss of kidney 
function [131]. Moll et al. adapted a method previously described for bioengineering skin to examine the process of injury-induced renal fibrosis [48]. Dermal fibroblasts were embedded within a collagen type I hydrogel and human renal PTCs were grown on top of the hydrogel in a monolayer allowing the visualization of the interaction of the two different cell types during drug-induced injury. Dermal fibroblasts were used because of their ability to respond to fibrosis inducing insults, but are a limitation of the model as renal fibroblasts would be more representative of the in vivo environment. The use of a monolayer of epithelial cells rather than a tubule structure with a lumen and fluid flow may alter key cell signaling pathways thus also biasing the findings. However, the study did show that injury to the epithelial cells did result in a phenotypic change in the fibroblasts to that of myofibroblasts which did not occur if the 3D culture were uninjured or epithelial cells were not present, thus justifying the model for further study.

A few different bioengineered renal cell carcinoma (RCC) models have been developed using different strategies. These include hydrogel systems similar to the 3D breast cancer models developed over the last two decades [127,128], slow, 3D rotary cell culture methods [129], and fibrin microbeads [12]. The hydrogel models have relied upon the embedding of RCC cells in either collagen type I [127] or Matrigel [128]. The benefit of these hydrogel models is similar to that of the normal kidney models used for ADPKD and DIN in that they allow for the visualization of cell invasion throughout the matrix environment upon different stimulations. The slow, 3D rotary cell culture method allows for the study of apoptosis in RCC cells upon matrix deprivation by eliminating the formation of spheroids which occur in matrix-deprived static culture systems and protect cells from anoikis [129]. By inhibiting spheroid formation, this model may be more useful for examining RCC in vitro. Finally, fibrin microbeads (FMB) have been shown to allow for cell differentiation and a higher culture volume due to increased surface area. This system has been used to examine the impact of gene therapy upon RCC survival [12]. Gene therapy has the potential to aid in the treatment of numerous kidney diseases including RCC where oncolytic adenovirus could be used to kill RCC cells. However, the kidney is barely targeted by current vectors for two possible reasons; first the glomerulus blocks the particles from accessing the kidney tubule due to size exclusion and second, the liver rapidly clears the particles from circulation. To examine the potential of oncolytic adenovirus for RCC treatment, Shimony et al. cultured RCC cells on FMB and showed that the RCC cells grown on FMB were slower to respond to oncolytic adenovirus both in terms of transduction and cell death than the same cells grown in monolayer culture. This may indicate the potential of this bioengineered system over simple monolayer 2D culture.

Nephronophthisis (NPHP) is an autosomal recessive cystic kidney disease which leads to end-stage renal failure in children and young adults [132]. The phenotype of the disease, in terms of cyst localization and secondary effects, differs from PKD. Ghosh developed a 3D model of the disease that is similar to the models used for PKD, by embedding cells in a hydrogel [130]. However, this model was developed for NPHP by inducing stable knockdown of the genes responsible for NPHP in mIMCD cells. As with the PKD models, this model allows for the monitoring of cyst formation. This study revealed the utility of 
these hydrogel-based 3D models for studying different kidney diseases that are defined by the formation of cysts from the epithelium.

\section{Glomerular Tissue Engineering}

The renal corpuscle which consists of the glomerulus, a tuft of capillaries surrounded by Bowman's capsule, is responsible for the ultrafiltration of the blood. The glomerulus consists of three major cell types, glomerular endothelial cells, mesangial cells, and podocytes, a specialized epithelial cell type. These cells function together in conjunction with the specialized mesangial membrane and glomerular basement membrane (GBM) in the ultrafiltration of blood. It is difficult to study the glomerulus in vitro due to its complicated structure and exacting function rendered by the specific, highly controlled interaction of cells and ECM. Tissue engineered models of diseases of the glomerulus do not exist and current efforts are being made to stably and reproducibly culture cells in vitro, mimic the GBM, and combine the cell types and GBM. In this section we will discuss efforts being made to establish cell cultures and engineer co-culture 3D models (Fig. 2).

The biggest issue in engineering the glomerulus is the in vitro culture of the different cells which tend to have a very short lifespan in vitro and require differentiation for proper cell function which limits cell proliferation. Isolated glomeruli have been previously utilized to study DIN and the associated changes in contraction [133-135]. Their addition to 3D hydrogels may be a helpful interim model of glomerular diseases. Recently a small number of immortalized glomerular cells have been established that rely on conditional immortalization in order to maintain proliferation and control the timing of differentiation necessary for cell function, including conditionally immortalized human podocytes [136] and conditionally immortalized human glomerular endothelial cells [137]. Additionally, Song et al. have attempted to generate podocytes from human induced pluripotent stem cells (iPSC) [138]. These cells had many phenotypic and functional similarities to podocytes and were capable of remaining in cell culture for longer time periods than primary human podocytes. Primary human mesangial cells are commercially available and an immortalized cell line has been recently established [139]. The complete characterization of these cell lines in 2D culture is necessary. Co-culture studies of mesangial cells and endothelial cells [140] and endothelial cells and podocytes [141] have been utilized to examine cell-cell interaction. It is possible that 3D culturing of these cells may result in changes in function and phenotype that may be beneficial for in vitro culture and better mimic in vivo phenotypes. In support of this hypothesis, Kitahara et al. showed that co-culturing of mesangial cells in direct contact with HUVECs and Matrigel encouraged the HUVECs to form a capillary network due to secretion of vascular endothelial growth factor (VEGF) by the mesangial cells [140].

The cells are not the only complex, unique aspect of the glomerulus. The structure of the GBM is highly specialized. It is relatively thick ranging between 300 and 350 microns and it has a unique composition consisting primarily of specific isoforms of collagen type IV [142]. In order to develop a tissue engineered model of the glomerulus, Slater et al. cocultured glomerular endothelial cells and podocytes on opposite sides of a nanofiber collagen type I/polycaprolactone (PCL) scaffold electrospun onto a micro-photopatterned 
nickel mesh [141]. This tri-layer model had a better barrier function than either cell type alone and may be used in the future to study how breakdown of either cell function may contribute to changes in glomerular filtration rates (GFR) that is associated with many kidney diseases. However, the scaffolding material described does not mimic the GBM in terms of cell signaling potential and changing the composition may better represent the in vivo GBM.

\section{Conclusions}

The past several years have seen a major push towards the development of better in vitro organ models and a greater appreciation for the utility of tissue engineered models. This shift has been fueled by an improved understanding of the limitations of animal models and an ethical desire to limit their use. Tissue engineering, especially kidney tissue engineering, has begun to benefit from this progress and should continue. In this review we have focused primarily on tissue engineered models of ADPKD and DIN due to the fact that the most progress has been associated with these models in the utilization of tissue engineering.

PKD and DIN models provide additional information to researchers. However, their implementation as reliable, reproducible, biologically accurate tools will require extensive future research. PKD models have primarily utilized animal cells, and a push towards the use of human cells has provided some progress. However, by using cells removed from patients already in the later stages of disease development, the early stages are often lost. These stages are critical for the development of treatments that may prevent cyst formation, and animal models are often still utilized for modeling these stages. DIN models are rather new, but their necessity has recently become better recognized. Current attempts require extensive further development as these systems must recapitulate in vivo drug metabolism, uptake, and mechanism of action in order to stand as biologically accurate models. It is not sufficient to produce an $\mathrm{LD}_{50}$ to describe drug reaction in tissue engineered models. Researchers also need to be able to show that the system can properly metabolize a drug, that the transport proteins are present and functional in the cells to allow proper uptake, and that the mechanism of cell death accurately recapitulates that seen in vivo. Extremely limited research into these aspects has been performed. Additionally, it remains difficult to define how the data generated in a 3D model translates to an in vivo environment. Research into this area is extremely lacking and needs to start immediately if tissue engineered kidney models of DIN are going to be useful for the development of new drugs.

To achieve the ultimate goal, to fully recapitulate the human kidney with respect to structure and function, systems that are capable of fully mimicking all key aspects of kidney function will be needed. This system will require a tubular component, the glomerulus, and a vascular network, combined with proper compartmentalized fluid flow throughout. We have described much of the progress towards achieving this goal including the individual components of cells and scaffolding and the progress made towards the application of these engineered models for the study of kidney disease. Development of the individual components must continue with the ultimate goal of combining them into one system. Cell lines capable of continued passaging, long term cell growth, and maintenance of proper phenotype and function are a necessity for the development of reliable, controllable, and 
reproducible chronic kidney injury models. Work needs to continue in the areas of cell immortalization, iPSC cell differentiation, and cell type specific isolation. The development and characterization of scaffolding systems capable of promoting cell organization and function while maintaining the complex architecture of the kidney, as well as maintaining tissue function for extended time frames to emulate chronic features, are needed in order to move beyond the current structural randomness of 3D tissues and the cell monolayer nature of microfluidics. Future work should focus upon the development of hybrid systems that have 3D tissue structure and complex cell interactions and organization combined with the fluid flow critical to in vivo kidney function. Incremental steps are needed to reach this goal, but they are achievable by building upon the successes described within this review.

\section{Acknowledgments}

We thank Dr. Jelena Rnjak-Kovacina for help in editing this document. Also, we thank our various collaborators on our kidney tissue studies including Dr. Barbara Ehrlich, Dr. Ivana Kuo, Dr. Ronald Perrone, Dr. Adrian Roth, and Dr. Laura Suter. We thank the NIH Tissue Engineering Resource Center (P41 EB002520) for support of aspects of our studies.

\section{Glossary}

3D

PKD

DIN

2D

3Rs

PTC

HPV

hTERT

THG

ECaC

MDCK

HGF

ES

EHS

PDMS

RGD

PEG

ECM

ADPKD three dimensional

polycystic kidney disease

drug-induced nephrotoxicity

two dimensional

replace, refine, reduce

proximal tubule epithelial cells

human papilloma virus

human telomerase reverse transcriptase

Tamm-Horsfall glycoprotein

epithelial calcium co-transporter

Madin-Darby canine kidney cells

hepatocyte growth factor

embryonic stem cell

Engelbreth-Holm-Swarm

polydimethylsiloxane

Arg-Gly-Asp

polyethylene glycol

extracellular matrix

autosomal dominant polycystic kidney disease 


\begin{tabular}{ll} 
PC1 & polycystin 1 \\
MT1-MMP & membrane-bound type I metalloproteinase \\
MMP & matrix metalloproteinase \\
CFTR & cystic fibrosis transmembrane conductance receptor \\
AMPK & adenosine monophosphate activated protein kinase \\
mTOR & mammalian target of rapamycin \\
mCCD & mouse collecting duct cells \\
cAMP & cyclic adenosine monophosphate \\
mIMCD & mouse Inner Medullary Collecting Duct cells \\
FDA & Food and Drug Administration \\
ADME & absorption, distribution, metabolism, and excretion \\
LDH & lactate dehydrogenase \\
Kim-1 & kidney injury marker 1 \\
NGAL & neutrophil gelatinase-associated lipocalin \\
RCC & renal cell carcinoma \\
FMB & fibrin microbeads \\
NPHP & nephronophthisis \\
GBM & glomerular basement membrane \\
iPSC & induced pluripotent stem cells \\
HUVECs & human umbilical vein endothelial cells \\
VEGF & vascular endothelial growth factor \\
PCL & polycaprolactone \\
GFP & glomerular filtration rate \\
\hline
\end{tabular}

\section{References}

[1]. Gibbons MC, Foley MA, Cardinal KO. Thinking inside the box: keeping tissue-engineered constructs in vitro for use as preclinical models. Tissue Eng Part B Rev. 2013; 19:14-30. [PubMed: 22800715]

[2]. Olson H, Betton G, Robinson D, Thomas K, Monro A, Kolaja G, Lilly P, Sanders J, Sipes G, Bracken W, Dorato M, Van DK, Smith P, Berger B, Heller A. Concordance of the toxicity of pharmaceuticals in humans and in animals. Regul. Toxicol. Pharmacol. 2000; 32:56-67. [PubMed: 11029269]

[3]. Knight A. Systematic reviews of animal experiments demonstrate poor contributions toward human healthcare. Rev Recent Clin. Trials. 2008; 3:89-96. [PubMed: 18474018]

[4]. Hartung T. Three Rs potential in the development and quality control of pharmaceuticals. ALTEX. 2001; 18(Suppl 1):3-13. [PubMed: 11854852] 
[5]. Hartung T, Bremer S, Casati S, Coecke S, Corvi R, Fortaner S, Gribaldo L, Halder M, Roi AJ, Prieto P, Sabbioni E, Worth A, Zuang V. ECVAM's response to the changing political environment for alternatives: consequences of the European Union chemicals and cosmetics policies. Altern. Lab Anim. 2003; 31:473-481. [PubMed: 15598174]

[6]. Desrochers TM, Suter L, Roth A, Kaplan DL. Bioengineered 3D Human Kidney Tissue, a Platform for the Determination of Nephrotoxicity. PLoS One. 2013; 8:e59219. [PubMed: 23516613]

[7]. Segal N, Andriani F, Pfeiffer L, Kamath P, Lin N, Satyamurthy K, Egles C, Garlick JA. The basement membrane microenvironment directs the normalization and survival of bioengineered human skin equivalents. Matrix Biol. 2008; 27:163-170. [PubMed: 18029161]

[8]. Mueller D, Kramer L, Hoffmann E, Klein S, Noor F. 3D organotypic HepaRG cultures as in vitro model for acute and repeated dose toxicity studies. Toxicol. 2013 In Vitro.

[9]. Mulhall HJ, Hughes MP, Kazmi B, Lewis MP, Labeed FH. Epithelial cancer cells exhibit different electrical properties when cultured in 2D and 3D environments. Biochim. Biophys. Acta. 2013; 1830:5136-5141. [PubMed: 23872353]

[10]. Krause S, Maffini MV, Soto AM, Sonnenschein C. A novel 3D in vitro culture model to study stromal-epithelial interactions in the mammary gland. Tissue Eng Part C. Methods. 2008; 14:261-271. [PubMed: 18694322]

[11]. Desrochers TM, Shamis Y, lt-Holland A, Kudo Y, Takata T, Wang G, Jackson-Grusby L, Garlick JA. The 3D tissue microenvironment modulates DNA methylation and E-cadherin expression in squamous cell carcinoma. Epigenetics. 2012; 7

[12]. Shimony N, Gorodetsky R, Marx G, Gal D, Rivkin R, Ben-Ari A, Landsman A, Haviv YS. Fibrin microbeads (FMB) as a 3D platform for kidney gene and cell therapy. Kidney Int. 2006; 69:625633. [PubMed: 16395256]

[13]. Subramanian B, Rudym D, Cannizzaro C, Perrone R, Zhou J, Kaplan DL. Tissue-engineered three-dimensional in vitro models for normal and diseased kidney. Tissue Eng Part A. 2010; 16:2821-2831. [PubMed: 20486787]

[14]. Smith PL, Buffington DA, Humes HD. Kidney epithelial cells. Methods Enzymol. 2006; 419:194-207. [PubMed: 17141057]

[15]. Boogaard PJ, Nagelkerke JF, Mulder GJ. Renal proximal tubular cells in suspension or in primary culture as in vitro models to study nephrotoxicity. Chem. Biol. Interact. 1990; 76:251291. [PubMed: 2225232]

[16]. Shimazui T, Schalken JA, Kawai K, Kawamoto R, van BA, Oosterwijk E, Akaza H. Role of complex cadherins in cell-cell adhesion evaluated by spheroid formation in renal cell carcinoma cell lines. Oncol. Rep. 2004; 11:357-360. [PubMed: 14719067]

[17]. Kim YK, Ko SH, Woo JS, Lee SH, Jung JS. Difference in $\mathrm{H} 2 \mathrm{O} 2$ toxicity between intact renal tubules and cultured proximal tubular cells. Biochem. Pharmacol. 1998; 56:489-495. [PubMed: 9763225]

[18]. Vickers AE, Fisher RL. Evaluation of drug-induced injury and human response in precision-cut tissue slices. Xenobiotica. 2013; 43:29-40. [PubMed: 23094640]

[19]. Cruz RH, Gumbleton M, Nicholls PJ. In vitro assessment of cephaloridine nephrotoxicity: comparison of renal cortical slice and renal tubule fragment techniques. J. Pharmacol. Methods. 1988; 19:185-192. [PubMed: 3393002]

[20]. Sprenger A, Kuttner V, Biniossek ML, Gretzmeier C, Boerries M, Mack C, Has C, BrucknerTuderman L, Dengjel J. Comparative quantitation of proteome alterations induced by aging or immortalization in primary human fibroblasts and keratinocytes for clinical applications. Mol. Biosyst. 2010; 6:1579-1582. [PubMed: 20454738]

[21]. Lipps C, May T, Hauser H, Wirth D. Eternity and functionality - rational access to physiologically relevant cell lines. Biol. Chem. 2013

[22]. Detrisac CJ, Sens MA, Garvin AJ, Spicer SS, Sens DA. Tissue culture of human kidney epithelial cells of proximal tubule origin. Kidney Int. 1984; 25:383-390. [PubMed: 6727133]

[23]. Racusen LC, Monteil C, Sgrignoli A, Lucskay M, Marouillat S, Rhim JG, Morin JP. Cell lines with extended in vitro growth potential from human renal proximal tubule: characterization, 
response to inducers, and comparison with established cell lines. J. Lab Clin. Med. 1997; 129:318-329. [PubMed: 9042817]

[24]. Orosz DE, Woost PG, Kolb RJ, Finesilver MB, Jin W, Frisa PS, Choo CK, Yau CF, Chan KW, Resnick MI, Douglas JG, Edwards JC, Jacobberger JW, Hopfer U. Growth, immortalization, and differentiation potential of normal adult human proximal tubule cells. Vitro Cell Dev. Biol. Anim. 2004; 40:22-34.

[25]. Cummings BS, Lasker JM, Lash LH. Expression of glutathione-dependent enzymes and cytochrome P450s in freshly isolated and primary cultures of proximal tubular cells from human kidney. J. Pharmacol. Exp. Ther. 2000; 293:677-685. [PubMed: 10773044]

[26]. Ryan MJ, Johnson G, Kirk J, Fuerstenberg SM, Zager RA, Torok-Storb B. HK-2: an immortalized proximal tubule epithelial cell line from normal adult human kidney. Kidney Int. 1994; 45:48-57. [PubMed: 8127021]

[27]. Baer PC, Geiger H. Human renal cells from the thick ascending limb and early distal tubule: characterization of primary isolated and cultured cells by reverse transcription polymerase chain reaction. Nephrology. (Carlton. ). 2008; 13:316-321. [PubMed: 18331438]

[28]. Tang S, Leung JC, Lam CW, Lai FM, Chan TM, Lai KN. In vitro studies of aquaporins 1 and 3 expression in cultured human proximal tubular cells: upregulation by transferrin but not albumin. Am. J. Kidney Dis. 2001; 38:317-330. [PubMed: 11479158]

[29]. Gunness P, Aleksa K, Kosuge K, Ito S, Koren G. Comparison of the novel HK-2 human renal proximal tubular cell line with the standard LLC-PK1 cell line in studying drug-induced nephrotoxicity. Can. J. Physiol Pharmacol. 2010; 88:448-455. [PubMed: 20555413]

[30]. Wu Y, Connors D, Barber L, Jayachandra S, Hanumegowda UM, Adams SP. Multiplexed assay panel of cytotoxicity in HK-2 cells for detection of renal proximal tubule injury potential of compounds. Toxicol. 2009; 23:1170-1178. In Vitro.

[31]. Zager RA, Johnson AC, Geballe A. Gentamicin suppresses endotoxin-driven TNF-alpha production in human and mouse proximal tubule cells. Am. J. Physiol Renal Physiol. 2007; 293:F1373-F1380. [PubMed: 17699551]

[32]. Wei Z, Amponsah PK, Al-Shatti M, Nie Z, Bandyopadhyay BC. Engineering of polarized tubular structures in a microfluidic device to study calcium phosphate stone formation. Lab Chip. 2012; 12:4037-4040. [PubMed: 22960772]

[33]. Kher R, Sha EC, Escobar MR, Andreoli EM, Wang P, Xu WM, Wandinger-Ness A, Bacallao RL. Ectopic expression of cadherin 8 is sufficient to cause cyst formation in a novel 3D collagen matrix renal tubule culture. Am. J. Physiol Cell Physiol. 2011; 301:C99-C105. [PubMed: 21389276]

[34]. Jang KJ, Mehr AP, Hamilton GA, McPartlin LA, Chung S, Suh KY, Ingber DE. Human kidney proximal tubule-on-a-chip for drug transport and nephrotoxicity assessment. Integr. Biol. (Camb. ). 2013

[35]. Wieser M, Stadler G, Jennings P, Streubel B, Pfaller W, Ambros P, Riedl C, Katinger H, Grillari J, Grillari-Voglauer R. hTERT alone immortalizes epithelial cells of renal proximal tubules without changing their functional characteristics. Am. J. Physiol Renal Physiol. 2008; 295:F1365-F1375. [PubMed: 18715936]

[36]. Hewitson TD, Grimwood L. Immuno and lectin histochemistry for renal light microscopy. Methods Mol. Biol. 2009; 466:133-147. [PubMed: 19148613]

[37]. Truong LD, Phung VT, Yoshikawa Y, Mattioli CA. Glycoconjugates in normal human kidney. A histochemical study using 13 biotinylated lectins. Histochemistry. 1988; 90:51-60. [PubMed: 2466021]

[38]. Xia Y, Nivet E, Sancho-Martinez I, Gallegos T, Suzuki K, Okamura D, Wu MZ, Dubova I, Esteban CR, Montserrat N, Campistol JM, Belmonte JC. Directed differentiation of human pluripotent cells to ureteric bud kidney progenitor-like cells. Nat Cell Biol. 2013

[39]. Montserrat N, Ramirez-Bajo MJ, Xia Y, Sancho-Martinez I, Moya-Rull D, Miquel-Serra L, Yang S, Nivet E, Cortina C, Gonzalez F, Izpisua Belmonte JC, Campistol JM. Generation of induced pluripotent stem cells from human renal proximal tubular cells with only two transcription factors, OCT4 and SOX2. J. Biol. Chem. 2012; 287:24131-24138. [PubMed: 22613719] 
[40]. Wang AZ, Wang JC, Ojakian GK, Nelson WJ. Determinants of apical membrane formation and distribution in multicellular epithelial MDCK cysts. Am. J. Physiol. 1994; 267:C473-C481. [PubMed: 8074182]

[41]. Chung IM, Enemchukwu NO, Khaja SD, Murthy N, Mantalaris A, Garcia AJ. Bioadhesive hydrogel microenvironments to modulate epithelial morphogenesis. Biomaterials. 2008; 29:2637-2645. [PubMed: 18377982]

[42]. Manivannan S, Gleghorn JP, Nelson CM. Engineered tissues to quantify collective cell migration during morphogenesis. Methods Mol. Biol. 2012; 886:173-182. [PubMed: 22639261]

[43]. Ibraghimov-Beskrovnaya O, Dackowski WR, Foggensteiner L, Coleman N, Thiru S, Petry LR, Burn TC, Connors TD, Van RT, Bradley J, Qian F, Onuchic LF, Watnick TJ, Piontek K, Hakim RM, Landes GM, Germino GG, Sandford R, Klinger KW. Polycystin: in vitro synthesis, in vivo tissue expression, and subcellular localization identifies a large membrane-associated protein. Proc. Natl. Acad. Sci. U. S. A. 1997; 94:6397-6402. [PubMed: 9177229]

[44]. Bukanov NO, Husson H, Dackowski WR, Lawrence BD, Clow PA, Roberts BL, Klinger KW, Ibraghimov-Beskrovnaya O. Functional polycystin-1 expression is developmentally regulated during epithelial morphogenesis in vitro: downregulation and loss of membrane localization during cystogenesis. Hum. Mol. Genet. 2002; 11:923-936. [PubMed: 11971874]

[45]. Choucha-Snouber L, Aninat C, Grsicom L, Madalinski G, Brochot C, Poleni PE, Razan F, Guillouzo CG, Legallais C, Corlu A, Leclerc E. Investigation of ifosfamide nephrotoxicity induced in a liver-kidney co-culture biochip. Biotechnol. Bioeng. 2013; 110:597-608. [PubMed: 22887128]

[46]. Choucha SL, Jacques S, Monge M, Legallais C, Leclerc E. Transcriptomic analysis of the effect of ifosfamide on MDCK cells cultivated in microfluidic biochips. Genomics. 2012; 100:27-34. [PubMed: 22580237]

[47]. Elberg G, Guruswamy S, Logan CJ, Chen L, Turman MA. Plasticity of epithelial cells derived from human normal and ADPKD kidneys in primary cultures. Cell Tissue Res. 2008; 331:495508. [PubMed: 18004594]

[48]. Moll S, Ebeling M, Weibel F, Farina A, raujo Del RA, Hoflack JC, Pomposiello S, Prunotto M. Epithelial cells as active player in fibrosis: findings from an in vitro model. PLoS One. 2013; 8:e56575. [PubMed: 23457584]

[49]. Rosines E, Johkura K, Zhang X, Schmidt HJ, Decambre M, Bush KT, Nigam SK. Constructing kidney-like tissues from cells based on programs for organ development: toward a method of in vitro tissue engineering of the kidney. Tissue Eng Part A. 2010; 16:2441-2455. [PubMed: 20214453]

[50]. Astashkina AI, Mann BK, Prestwich GD, Grainger DW. Comparing predictive drug nephrotoxicity biomarkers in kidney 3-D primary organoid culture and immortalized cell lines. Biomaterials. 2012; 33:4712-4721. [PubMed: 22475530]

[51]. Astashkina AI, Mann BK, Prestwich GD, Grainger DW. A 3-D organoid kidney culture model engineered for high-throughput nephrotoxicity assays. Biomaterials. 2012; 33:4700-4711. [PubMed: 22444643]

[52]. Egles C, Garlick JA, Shamis Y. Three-dimensional human tissue models of wounded skin. Methods Mol. Biol. 2010; 585:345-359. [PubMed: 19908015]

[53]. Kural MH, Billiar KL. Regulating tension in three-dimensional culture environments. Exp. Cell Res. 2013

[54]. Yeung T, Georges PC, Flanagan LA, Marg B, Ortiz M, Funaki M, Zahir N, Ming W, Weaver V, Janmey PA. Effects of substrate stiffness on cell morphology, cytoskeletal structure, and adhesion. Cell Motil. Cytoskeleton. 2005; 60:24-34. [PubMed: 15573414]

[55]. Sechler JL, Corbett SA, Wenk MB, Schwarzbauer JE. Modulation of cell-extracellular matrix interactions. Ann. N. Y. Acad. Sci. 1998; 857:143-154. [PubMed: 9917839]

[56]. Grogan SP, Chen X, Sovani S, Taniguchi N, Colwell CW Jr, Lotz M, D’Lima D. Influence of cartilage extracellular matrix molecules on cell phenotype and neocartilage formation. Tissue Eng Part A. 2013 
[57]. Grover CN, Cameron RE, Best SM. Investigating the morphological, mechanical and degradation properties of scaffolds comprising collagen, gelatin and elastin for use in soft tissue engineering. J. Mech. Behav. Biomed. Mater. 2012; 10:62-74. [PubMed: 22520419]

[58]. Subramanian B, Ko WC, Yadav V, Desrochers TM, Perrone RD, Zhou J, Kaplan DL. The regulation of cystogenesis in a tissue engineered kidney disease system by abnormal matrix interactions. Biomaterials. 2012; 33:8383-8394. [PubMed: 22940218]

[59]. Ross EA, Williams MJ, Hamazaki T, Terada N, Clapp WL, Adin C, Ellison GW, Jorgensen M, Batich CD. Embryonic stem cells proliferate and differentiate when seeded into kidney scaffolds. J. Am. Soc. Nephrol. 2009; 20:2338-2347. [PubMed: 19729441]

[60]. Ross EA, Abrahamson DR, St JP, Clapp WL, Williams MJ, Terada N, Hamazaki T, Ellison GW, Batich CD. Mouse stem cells seeded into decellularized rat kidney scaffolds endothelialize and remodel basement membranes. Organogenesis. 2012; 8:49-55. [PubMed: 22692231]

[61]. Song JJ, Guyette JP, Gilpin SE, Gonzalez G, Vacanti JP, Ott HC. Regeneration and experimental orthotopic transplantation of a bioengineered kidney. Nat Med. 2013; 19:646-651. [PubMed: 23584091]

[62]. Orlando G, Farney AC, Iskandar SS, Mirmalek-Sani SH, Sullivan DC, Moran E, AbouShwareb T, De CP, Wood KJ, Stratta RJ, Atala A, Yoo JJ, Soker S. Production and implantation of renal extracellular matrix scaffolds from porcine kidneys as a platform for renal bioengineering investigations. Ann. Surg. 2012; 256:363-370. [PubMed: 22691371]

[63]. Sullivan DC, Mirmalek-Sani SH, Deegan DB, Baptista PM, AbouShwareb T, Atala A, Yoo JJ. Decellularization methods of porcine kidneys for whole organ engineering using a highthroughput system. Biomaterials. 2012; 33:7756-7764. [PubMed: 22841923]

[64]. Nakayama KH, Batchelder CA, Lee CI, Tarantal AF. Decellularized rhesus monkey kidney as a three-dimensional scaffold for renal tissue engineering. Tissue Eng Part A. 2010; 16:2207-2216. [PubMed: 20156112]

[65]. Nakayama KH, Batchelder CA, Lee CI, Tarantal AF. Renal tissue engineering with decellularized rhesus monkey kidneys: age-related differences. Tissue Eng Part A. 2011; 17:2891-2901. [PubMed: 21902603]

[66]. Nakayama KH, Lee CC, Batchelder CA, Tarantal AF. Tissue specificity of decellularized rhesus monkey kidney and lung scaffolds. PLoS One. 2013; 8:e64134. [PubMed: 23717553]

[67]. Huh D, Hamilton GA, Ingber DE. From 3D cell culture to organs-on-chips. Trends Cell Biol. 2011; 21:745-754. [PubMed: 22033488]

[68]. Duan Y, Gotoh N, Yan Q, Du Z, Weinstein AM, Wang T, Weinbaum S. Shear-induced reorganization of renal proximal tubule cell actin cytoskeleton and apical junctional complexes. Proc. Natl. Acad. Sci. U. S. A. 2008; 105:11418-11423. [PubMed: 18685100]

[69]. Essig M, Terzi F, Burtin M, Friedlander G. Mechanical strains induced by tubular flow affect the phenotype of proximal tubular cells. Am. J. Physiol Renal Physiol. 2001; 281:F751-F762. [PubMed: 11553522]

[70]. Cai Z, Xin J, Pollock DM, Pollock JS. Shear stress-mediated NO production in inner medullary collecting duct cells. Am. J. Physiol Renal Physiol. 2000; 279:F270-F274. [PubMed: 10919845]

[71]. Liu W, Xu S, Woda C, Kim P, Weinbaum S, Satlin LM. Effect of flow and stretch on the [Ca2+]i response of principal and intercalated cells in cortical collecting duct. Am. J. Physiol Renal Physiol. 2003; 285:F998-F1012. [PubMed: 12837680]

[72]. Baudoin R, Griscom L, Monge M, Legallais C, Leclerc E. Development of a renal microchip for in vitro distal tubule models. Biotechnol. Prog. 2007; 23:1245-1253. [PubMed: 17725364]

[73]. Jang KJ, Suh KY. A multi-layer microfluidic device for efficient culture and analysis of renal tubular cells. Lab Chip. 2010; 10:36-42. [PubMed: 20024048]

[74]. Gao X, Tanaka Y, Sugii Y, Mawatari K, Kitamori T. Basic structure and cell culture condition of a bioartificial renal tubule on chip towards a cell-based separation microdevice. Anal. Sci. 2011; 27:907-912. [PubMed: 21908919]

[75]. Frohlich EM, Alonso JL, Borenstein JT, Zhang X, Arnaout MA, Charest JL. Topographicallypatterned porous membranes in a microfluidic device as an in vitro model of renal reabsorptive barriers. Lab Chip. 2013; 13:2311-2319. [PubMed: 23636129] 
[76]. Mu X, Zheng W, Xiao L, Zhang W, Jiang X. Engineering a 3D vascular network in hydrogel for mimicking a nephron. Lab Chip. 2013; 13:1612-1618. [PubMed: 23455642]

[77]. Praetorius HA, Spring KR. Removal of the MDCK cell primary cilium abolishes flow sensing. J. Membr. Biol. 2003; 191:69-76. [PubMed: 12532278]

[78]. Praetorius HA, Spring KR. The renal cell primary cilium functions as a flow sensor. Curr. Opin. Nephrol. Hypertens. 2003; 12:517-520. [PubMed: 12920399]

[79]. Joly D, Hummel A, Ruello A, Knebelmann B. Ciliary function of polycystins: a new model for cystogenesis. Nephrol. Dial. Transplant. 2003; 18:1689-1692. [PubMed: 12937209]

[80]. Harris PC, Torres VE. Polycystic kidney disease. Annu. Rev Med. 2009; 60:321-337. [PubMed: 18947299]

[81]. Grantham JJ. Clinical practice. Autosomal dominant polycystic kidney disease. N. Engl. J. Med. 2008; 359:1477-1485. [PubMed: 18832246]

[82]. Torres VE, Harris PC. Autosomal dominant polycystic kidney disease: the last 3 years. Kidney Int. 2009; 76:149-168. [PubMed: 19455193]

[83]. Gallagher AR, Germino GG, Somlo S. Molecular advances in autosomal dominant polycystic kidney disease. Adv. Chronic. Kidney Dis. 2010; 17:118-130. [PubMed: 20219615]

[84]. Grantham JJ, Uchic M, Cragoe EJ Jr. Kornhaus J, Grantham JA, Donoso V, Mangoo-Karim R, Evan A, McAteer J. Chemical modification of cell proliferation and fluid secretion in renal cysts. Kidney Int. 1989; 35:1379-1389. [PubMed: 2770116]

[85]. Mangoo-Karim R, Uchic ME, Grant M, Shumate WA, Calvet JP, Park CH, Grantham JJ. Renal epithelial fluid secretion and cyst growth: the role of cyclic AMP. FASEB J. 1989; 3:2629-2632. [PubMed: 2480260]

[86]. Li H, Findlay IA, Sheppard DN. The relationship between cell proliferation, Cl-secretion, and renal cyst growth: a study using CFTR inhibitors. Kidney Int. 2004; 66:1926-1938. [PubMed: 15496164]

[87]. Orellana SA, Marfella-Scivittaro C. Distinctive cyclic AMP-dependent protein kinase subunit localization is associated with cyst formation and loss of tubulogenic capacity in Madin-Darby canine kidney cell clones. J. Biol. Chem. 2000; 275:21233-21240. [PubMed: 10767293]

[88]. Qian F, Watnick TJ, Onuchic LF, Germino GG. The molecular basis of focal cyst formation in human autosomal dominant polycystic kidney disease type I. Cell. 1996; 87:979-987. [PubMed: 8978603]

[89]. Liu B, Li C, Liu Z, Dai Z, Tao Y. Increasing extracellular matrix collagen level and MMP activity induces cyst development in polycystic kidney disease. BMC. Nephrol. 2012; 13:109. [PubMed: 22963260]

[90]. Nakamura T, Ushiyama C, Suzuki S, Ebihara I, Shimada N, Koide H. Elevation of serum levels of metalloproteinase-1, tissue inhibitor of metalloproteinase-1 and type IV collagen, and plasma levels of metalloproteinase-9 in polycystic kidney disease. Am. J. Nephrol. 2000; 20:32-36. [PubMed: 10644865]

[91]. Bukanov NO, Moreno SE, Natoli TA, Rogers KA, Smith LA, Ledbetter SR, Oumata N, Galons $\mathrm{H}$, Meijer L, Ibraghimov-Beskrovnaya O. CDK inhibitors R-roscovitine and S-CR8 effectively block renal and hepatic cystogenesis in an orthologous model of ADPKD. Cell Cycle. 2012; 11:4040-4046. [PubMed: 23032260]

[92]. Zhou H, Gao J, Zhou L, Li X, Li W, Li X, Xia Y, Yang B. Ginkgolide B inhibits renal cyst development in in vitro and in vivo cyst models. Am. J. Physiol Renal Physiol. 2012; 302:F1234-F1242. [PubMed: 22338085]

[93]. Takiar V, Nishio S, Seo-Mayer P, King JD Jr. Li H, Zhang L, Karihaloo A, Hallows KR, Somlo S, Caplan MJ. Activating AMP-activated protein kinase (AMPK) slows renal cystogenesis. Proc. Natl. Acad. Sci. U. S. A. 2011; 108:2462-2467. [PubMed: 21262823]

[94]. Montesano R, Ghzili H, Carrozzino F, Rossier BC, Feraille E. cAMP-dependent chloride secretion mediates tubule enlargement and cyst formation by cultured mammalian collecting duct cells. Am. J. Physiol Renal Physiol. 2009; 296:F446-F457. [PubMed: 19052103]

[95]. Wallace DP. Cyclic AMP-mediated cyst expansion. Biochim. Biophys. Acta. 2011; 1812:12911300. [PubMed: 21118718] 
[96]. Carone FA, Nakamura S, Bacallao R, Nelson WJ, Khokha M, Kanwar YS. Impaired tubulogenesis of cyst-derived cells from autosomal dominant polycystic kidneys. Kidney Int. 1995; 47:861-868. [PubMed: 7752585]

[97]. Wallace DP, Grantham JJ, Sullivan LP. Chloride and fluid secretion by cultured human polycystic kidney cells. Kidney Int. 1996; 50:1327-1336. [PubMed: 8887295]

[98]. Sullivan LP, Wallace DP, Gover T, Welling PA, Yamaguchi T, Maser R, Eppler JW, Grantham JJ. Sulfonylurea-sensitive $\mathrm{K}(+)$ transport is involved in $\mathrm{Cl}(-)$ secretion and cyst trowth by cultured ADPKD cells. J. Am. Soc. Nephrol. 2002; 13:2619-2627. [PubMed: 12397031]

[99]. Yamaguchi T, Reif GA, Calvet JP, Wallace DP. Sorafenib inhibits cAMP-dependent ERK activation, cell proliferation, and in vitro cyst growth of human ADPKD cyst epithelial cells. Am. J. Physiol Renal Physiol. 2010; 299:F944-F951. [PubMed: 20810616]

[100]. Reif GA, Yamaguchi T, Nivens E, Fujiki H, Pinto CS, Wallace DP. Tolvaptan inhibits ERKdependent cell proliferation, $\mathrm{Cl}(-)$ secretion, and in vitro cyst growth of human ADPKD cells stimulated by vasopressin. Am. J. Physiol Renal Physiol. 2011; 301:F1005-F1013. [PubMed: 21816754]

[101]. Jansson K, Nguyen AN, Magenheimer BS, Reif GA, Aramadhaka LR, Bello-Reuss E, Wallace DP, Calvet JP, Blanco G. Endogenous concentrations of ouabain act as a cofactor to stimulate fluid secretion and cyst growth of in vitro ADPKD models via cAMP and EGFR-Src-MEK pathways. Am. J. Physiol Renal Physiol. 2012; 303:F982-F990. [PubMed: 22859406]

[102]. Buchholz B, Klanke B, Schley G, Bollag G, Tsai J, Kroening S, Yoshihara D, Wallace DP, Kraenzlin B, Gretz N, Hirth P, Eckardt KU, Bernhardt WM. The Raf kinase inhibitor PLX5568 slows cyst proliferation in rat polycystic kidney disease but promotes renal and hepatic fibrosis. Nephrol. Dial. Transplant. 2011; 26:3458-3465. [PubMed: 21804086]

[103]. Swenson-Fields KI, Vivian CJ, Salah SM, Peda JD, Davis BM, van RN, Wallace DP, Fields TA. Macrophages promote polycystic kidney disease progression. Kidney Int. 2013; 83:855-864. [PubMed: 23423256]

[104]. Karihaloo A, Koraishy F, Huen SC, Lee Y, Merrick D, Caplan MJ, Somlo S, Cantley LG. Macrophages promote cyst growth in polycystic kidney disease. J. Am. Soc. Nephrol. 2011; 22:1809-1814. [PubMed: 21921140]

[105]. Watnick TJ, Germino GG. Polycystic kidney disease: Polycystin-1 and polycystin-2-it's complicated. Nat Rev Nephrol. 2013; 9:249-250. [PubMed: 23567275]

[106]. Low SH, Vasanth S, Larson CH, Mukherjee S, Sharma N, Kinter MT, Kane ME, Obara T, Weimbs T. Polycystin-1, STAT6, and P100 function in a pathway that transduces ciliary mechanosensation and is activated in polycystic kidney disease. Dev. Cell. 2006; 10:57-69. [PubMed: 16399078]

[107]. Weimbs T. Polycystic kidney disease and renal injury repair: common pathways, fluid flow, and the function of polycystin-1. Am. J. Physiol Renal Physiol. 2007; 293:F1423-F1432. [PubMed: 17715262]

[108]. Food and Drug Administration. Innovation or Stagnation: Challenge and opportunity on the critical path to new medical products. Food and Drug Administration; Washington, DC: 2004.

[109]. Choudhury D, Ahmed Z. Drug-associated renal dysfunction and injury. Nat Clin. Pract. Nephrol. 2006; 2:80-91. [PubMed: 16932399]

[110]. Fuchs TC, Hewitt P. Biomarkers for drug-induced renal damage and nephrotoxicity-an overview for applied toxicology. AAPS. J. 2011; 13:615-631. [PubMed: 21969220]

[111]. Pannu N, Nadim MK. An overview of drug-induced acute kidney injury. Crit Care Med. 2008; 36:S216-S223. [PubMed: 18382197]

[112]. Zbinden G. Predictive value of animal studies in toxicology. Regul. Toxicol. Pharmacol. 1991; 14:167-177. [PubMed: 1792351]

[113]. Knight A. Systematic reviews of animal experiments demonstrate poor human clinical and toxicological utility. Altern. Lab Anim. 2007; 35:641-659. [PubMed: 18186670]

[114]. Fry JR, Wiebkin P, Kao J, Jones CA, Gwynn J, Bridges JW. A comparison of drugmetabolizing capability in isolated viable rat hepatocytes and renal tubule fragments. Xenobiotica. 1978; 8:113-120. [PubMed: 626003] 
[115]. Keane WF, Welch R, Gekker G, Peterson PK. Mechanism of Escherichia coli alpha-hemolysininduced injury to isolated renal tubular cells. Am. J. Pathol. 1987; 126:350-357. [PubMed: 3030115]

[116]. Keane WF, Gekker G, Schlievert PM, Peterson PK. Enhancement of endotoxin-induced isolated renal tubular cell injury by toxic shock syndrome toxin 1. Am. J. Pathol. 1986; 122:169-176. [PubMed: 3079956]

[117]. Dieterle F, Sistare F, Goodsaid F, Papaluca M, Ozer JS, Webb CP, Baer W, Senagore A, Schipper MJ, Vonderscher J, Sultana S, Gerhold DL, Phillips JA, Maurer G, Carl K, Laurie D, Harpur E, Sonee M, Ennulat D, Holder D, ndrews-Cleavenger D, Gu YZ, Thompson KL, Goering PL, Vidal JM, Abadie E, Maciulaitis R, Jacobson-Kram D, Defelice AF, Hausner EA, Blank M, Thompson A, Harlow P, Throckmorton D, Xiao S, Xu N, Taylor W, Vamvakas S, Flamion B, Lima BS, Kasper P, Pasanen M, Prasad K, Troth S, Bounous D, Robinson-Gravatt D, Betton G, Davis MA, Akunda J, McDuffie JE, Suter L, Obert L, Guffroy M, Pinches M, Jayadev S, Blomme EA, Beushausen SA, Barlow VG, Collins N, Waring J, Honor D, Snook S, Lee J, Rossi P, Walker E, Mattes W. Renal biomarker qualification submission: a dialog between the FDA-EMEA and Predictive Safety Testing Consortium. Nat Biotechnol. 2010; 28:455-462. [PubMed: 20458315]

[118]. Sung JH, Shuler ML. A micro cell culture analog (microCCA) with 3-D hydrogel culture of multiple cell lines to assess metabolism-dependent cytotoxicity of anti-cancer drugs. Lab Chip. 2009; 9:1385-1394. [PubMed: 19417905]

[119]. Chang R, Emami K, Wu H, Sun W. Biofabrication of a three-dimensional liver micro-organ as an in vitro drug metabolism model. Biofabrication. 2010; 2:1-11.

[120]. Lan SF, Starly B. Alginate based 3D hydrogels as an in vitro co-culture model platform for the toxicity screening of new chemical entities. Toxicol. Appl. Pharmacol. 2011; 256:62-72.

[PubMed: 21839104]

[121]. Nakamura K, Mizutani R, Sanbe A, Enosawa S, Kasahara M, Nakagawa A, Ejiri Y, Murayama N, Miyamoto Y, Torii T, Kusakawa S, Yamauchi J, Fukuda M, Yamazaki H, Tanoue A. Evaluation of drug toxicity with hepatocytes cultured in a micro-space cell culture system. J. Biosci. Bioeng. 2011; 111:78-84. [PubMed: 20837398]

[122]. Canton I, Cole DM, Kemp EH, Watson PF, Chunthapong J, Ryan AJ, MacNeil S, Haycock JW. Development of a 3D human in vitro skin co-culture model for detecting irritants in real-time. Biotechnol. Bioeng. 2010; 106:794-803. [PubMed: 20564616]

[123]. Hu T, Khambatta ZS, Hayden PJ, Bolmarcich J, Binder RL, Robinson MK, Carr GJ, Tiesman JP, Jarrold BB, Osborne R, Reichling TD, Nemeth ST, Aardema MJ. Xenobiotic metabolism gene expression in the EpiDermin vitro 3D human epidermis model compared to human skin. Toxicol. 2010; 24:1450-1463. In Vitro.

[124]. Kirsch-Volders M, Decordier I, Elhajouji A, Plas G, Aardema MJ, Fenech M. In vitro genotoxicity testing using the micronucleus assay in cell lines, human lymphocytes and 3D human skin models. Mutagenesis. 2011; 26:177-184. [PubMed: 21164200]

[125]. El MM, Laurent G, Mingeot-Leclercq MP, Tulkens PM. Gentamicin-induced apoptosis in renal cell lines and embryonic rat fibroblasts. Toxicol. Sci. 2000; 56:229-239. [PubMed: 10869472]

[126]. Charytan D, Kuntz RE. The exclusion of patients with chronic kidney disease from clinical trials in coronary artery disease. Kidney Int. 2006; 70:2021-2030. [PubMed: 17051142]

[127]. Zhou MI, Foy RL, Chitalia VC, Zhao J, Panchenko MV, Wang H, Cohen HT. Jade-1, a candidate renal tumor suppressor that promotes apoptosis. Proc. Natl. Acad. Sci. U. S. A. 2005; 102:11035-11040. [PubMed: 16046545]

[128]. Koochekpour S, Jeffers M, Wang PH, Gong C, Taylor GA, Roessler LM, Stearman R, Vasselli JR, Stetler-Stevenson WG, Kaelin WG Jr. Linehan WM, Klausner RD, Gnarra JR, Vande Woude GF. The von Hippel-Lindau tumor suppressor gene inhibits hepatocyte growth factor/scatter factor-induced invasion and branching morphogenesis in renal carcinoma cells. Mol. Cell Biol. 1999; 19:5902-5912. [PubMed: 10454537]

[129]. Shimony N, Avrahami I, Gorodetsky R, Elkin G, Tzukert K, Zangi L, Levdansky L, Krasny L, Haviv YS. A 3D rotary renal and mesenchymal stem cell culture model unveils cell death mechanisms induced by matrix deficiency and low shear stress. Nephrol. Dial. Transplant. 2008; 23:2071-2080. [PubMed: 18344240] 
[130]. Ghosh AK, Hurd T, Hildebrandt F. 3D spheroid defects in NPHP knockdown cells are rescued by the somatostatin receptor agonist octreotide. Am. J. Physiol Renal Physiol. 2012; 303:F1225F1229. [PubMed: 22832925]

[131]. Grgic I, Campanholle G, Bijol V, Wang C, Sabbisetti VS, Ichimura T, Humphreys BD, Bonventre JV. Targeted proximal tubule injury triggers interstitial fibrosis and glomerulosclerosis. Kidney Int. 2012; 82:172-183. [PubMed: 22437410]

[132]. Hildebrandt F, Zhou W. Nephronophthisis-associated ciliopathies. J. Am. Soc. Nephrol. 2007; 18:1855-1871. [PubMed: 17513324]

[133]. Rodriguez-Barbero A, L’Azou B, Cambar J, Lopez-Novoa JM. Potential use of isolated glomeruli and cultured mesangial cells as in vitro models to assess nephrotoxicity. Cell Biol. Toxicol. 2000; 16:145-153. [PubMed: 11032358]

[134]. Gonzalez R, Redon P, Lakhdar B, Potaux L, Cambar J, Aparicio M. Cyclosporin nephrotoxicity assessed in isolated human glomeruli and cultured mesangial cells. Toxicol. 1990; 4:391-395. In Vitro.

[135]. Potier M, L’Azou B, Cambar J. Isolated glomeruli and cultured mesangial cells as in vitro models to study immunosuppressive agents. Cell Biol. Toxicol. 1996; 12:263-270. [PubMed: 9034619]

[136]. Saleem MA, O’Hare MJ, Reiser J, Coward RJ, Inward CD, Farren T, Xing CY, Ni L, Mathieson PW, Mundel P. A conditionally immortalized human podocyte cell line demonstrating nephrin and podocin expression. J. Am. Soc. Nephrol. 2002; 13:630-638. [PubMed: 11856766]

[137]. Satchell SC, Tasman CH, Singh A, Ni L, Geelen J, von Ruhland CJ, O'Hare MJ, Saleem MA, van den Heuvel LP, Mathieson PW. Conditionally immortalized human glomerular endothelial cells expressing fenestrations in response to VEGF. Kidney Int. 2006; 69:1633-1640. [PubMed: 16557232]

[138]. Song B, Smink AM, Jones CV, Callaghan JM, Firth SD, Bernard CA, Laslett AL, Kerr PG, Ricardo SD. The directed differentiation of human iPS cells into kidney podocytes. PLoS One. 2012; 7:e46453. [PubMed: 23029522]

[139]. L'Azou B, Dubus I, Ohayon-Court, Cambar J. Human glomerular mesangial IP15 cell line as a suitable model for in vitro cadmium cytotoxicity studies. Cell Biol. Toxicol. 2007; 23:267-278. [PubMed: 17180447]

[140]. Kitahara T, Hiromura K, Ikeuchi H, Yamashita S, Kobayashi S, Kuroiwa T, Kaneko Y, Ueki K, Nojima Y. Mesangial cells stimulate differentiation of endothelial cells to form capillary-like networks in a three-dimensional culture system. Nephrol. Dial. Transplant. 2005; 20:42-49. [PubMed: 15546889]

[141]. Slater SC, Beachley V, Hayes T, Zhang D, Welsh GI, Saleem MA, Mathieson PW, Wen X, Su $\mathrm{B}$, Satchell SC. An in vitro model of the glomerular capillary wall using electrospun collagen nanofibres in a bioartificial composite basement membrane. PLoS One. 2011; 6:e20802. [PubMed: 21731625]

[142]. Miner JH. The glomerular basement membrane. Exp. Cell Res. 2012; 318:973-978. [PubMed: 22410250] 


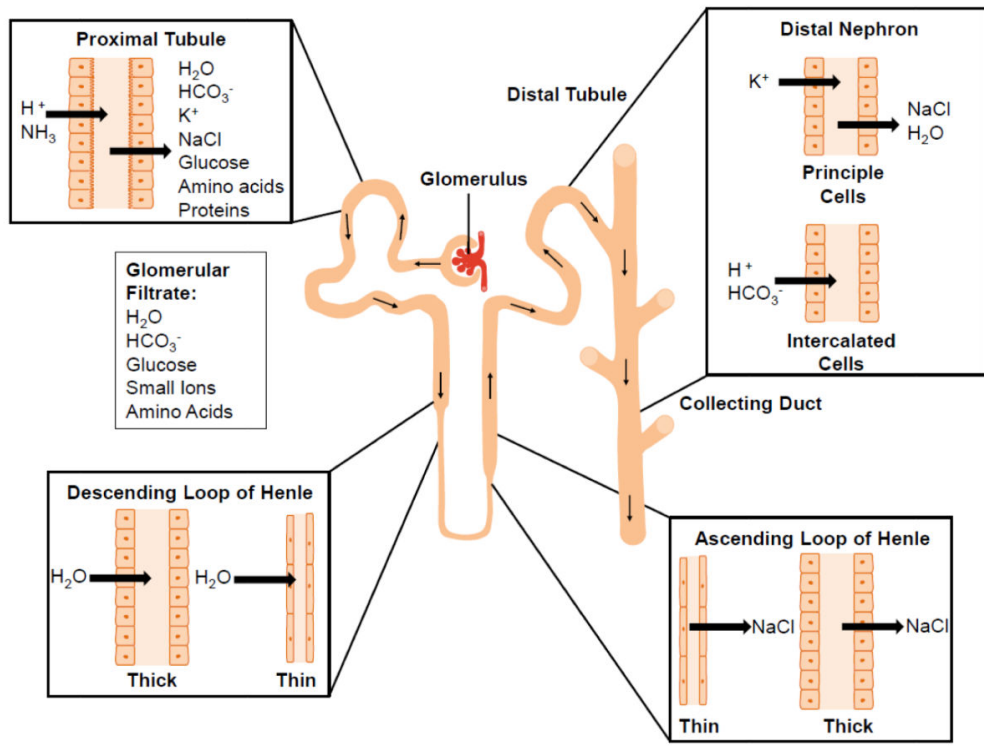

Fig.1.

Schematic representation of the different cellular components of the nephron and their roles in vivo. 


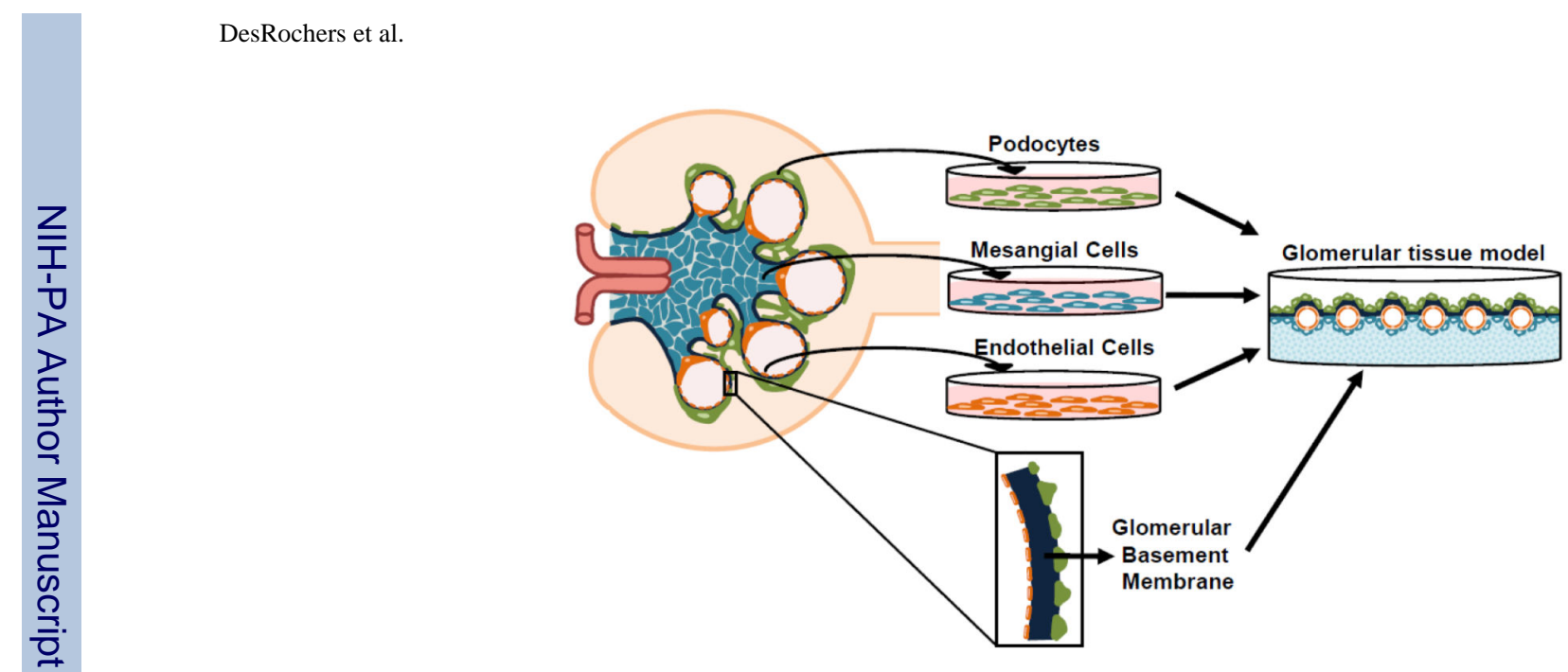

Fig. 2.

Schematic representation of the process of glomerular tissue engineering. 


\section{Table 1}

Comparison of different tissue engineered kidney disease models

\begin{tabular}{|c|c|c|}
\hline Disease & Cell Source & Reference \\
\hline \multirow[t]{6}{*}{ Polycystic Kidney Disease } & MDCK & {$[44,84-87,89,91-93]$} \\
\hline & Mouse & \\
\hline & $\begin{array}{l}\text { Immortalized } \\
\text { collecting duct }\end{array}$ & {$[94]$} \\
\hline & $\begin{array}{l}\text { PKD1 } 1^{\text {null/null }} \\
\text { embryonic kidney } \\
\text { with fibroblasts }\end{array}$ & {$[13,98]$} \\
\hline & $\begin{array}{l}\text { Inner Medullary } \\
\text { Collecting Duct cells }\end{array}$ & {$[58]$} \\
\hline & $\begin{array}{l}\text { Human primary epithelial cells } \\
\text { from ADPKD cysts }\end{array}$ & {$[91,96,97,99-101,103]$} \\
\hline \multirow[t]{5}{*}{ Drug-Induced Nephrotoxicity } & MDCK & {$[45,46]$} \\
\hline & Mouse Kidney Tubule & {$[50,51]$} \\
\hline & Human & \\
\hline & $\begin{array}{l}\text { Immortalized } \\
\text { proximal tubule } \\
\text { epithelial cells }\end{array}$ & {$[6]$} \\
\hline & $\begin{array}{l}\text { Primary proximal } \\
\text { tubule epithelial cells }\end{array}$ & {$[34]$} \\
\hline Fibrosis & $\begin{array}{l}\text { Human proximal tubule } \\
\text { epithelial cells with dermal } \\
\text { fibroblasts }\end{array}$ & {$[48]$} \\
\hline Renal Cell Carcinoma & Human RCC cells & {$[12,127-129]$} \\
\hline Nephronophthisis & $\begin{array}{l}\text { Mouse Inner Medullary } \\
\text { Collecting Ducts cells }\end{array}$ & {$[130]$} \\
\hline
\end{tabular}

